\title{
Regionality of long-term trends and interannual variation of seasonal precipitation over India
}

\author{
Azusa Fukushima ${ }^{*^{*}} \mathbb{D}$, Hironari Kanamori ${ }^{2}$ and Jun Matsumoto ${ }^{3,4}$
}

\begin{abstract}
This study investigated the long-term trends and interannual variations (IAVs) of seasonal precipitation during two different periods in India and their relation to atmospheric circulation. To focus on the relation between the regional characteristics of precipitation and the large-scale circulation system, we defined homogeneous regions based on pentad rainfall seasonality using hierarchical cluster analysis. Seven obtained clusters (regions) were used to analyze the long-term trends, IAVs, and their relation to atmospheric circulation. Seasonal precipitation showed no remarkable trend in most regions and seasons, which implies the effect of IAV in seasonal precipitation is greater than the long-term trend. Based on regression analysis, the IAV of seasonal precipitation and its relation to atmospheric circulation over the ocean surrounding India were detected for each season. Enhancement of the southwesterly monsoon flow over the Indian Ocean and the strength of the southeasterly wind related to the activity of the monsoon trough around the Gangetic Plain both affected the increase of summer monsoon precipitation in regions CL3 (central and eastern India) and CL6 (western coast of the Arabian Sea in southern India). In contrast, neither region CL5 (eastern coastal region of southern India) nor CL7 (northeastern India and part of the western coastal region of southern India) showed a relationship between IAV of summer monsoon precipitation and the southwesterly flow or the southeasterly flow over the Indian Ocean or the Gangetic Plain, respectively. Region CL5 showed strong correlation with the northeasterly monsoon flow (strength of the southeasterly flow over the Bay of Bengal) during the post-monsoon season. Other regions showed no relation with the northeasterly flow during the post-monsoon season. Furthermore, IAV of precipitation in region CL7 showed no correlation with either the southwesterly monsoon during the summer monsoon season or the northeasterly monsoon during the post-monsoon season.
\end{abstract}

Keywords: Indian monsoon variability, Rainfall seasonality, Cluster analysis, Water vapor convergence, Low-level jet stream

\section{Introduction}

Seasonal transition of precipitation over India is strongly characterized by the Indian summer monsoon. In general, summer monsoon precipitation (accumulated during June-September) contributes greatly to annual precipitation in most parts of India with a ratio of approximately 80\% (e.g., Parthasarathy et al. 1993, 1994). The Indian summer monsoon is caused primarily by land-sea thermal contrast (e.g., Meehl 1994). The mean monsoon flow over the Indian Ocean can be detected as a cross-equatorial low-level jet stream (LLJ). Over the

\footnotetext{
* Correspondence: azfuku@human.kobegakuin.ac.jp

${ }^{1}$ Faculty of Humanities and Sciences, Kobe Gakuin University, 518 Arise,

Ikawadani-cho, Nishi-ku, Kobe, Hyogo 651-2180, Japan

Full list of author information is available at the end of the article
}

Indian Ocean, southwesterly flow (Southwest Monsoon; hereafter, SWM) prevails during summer and northeasterly flow (Northeast Monsoon; hereafter, NEM) dominates during the post-monsoon and winter seasons. The winter rainy season in southeastern regions of India is caused by the NEM. Precipitation during October-December contributes $40-50 \%$ of annual precipitation in the southeast of the Indian subcontinent (Zubair and Ropelewski 2006). However, large regional differences of rainfall patterns in India, not only in summer but also in other seasons, have been noted (e.g., Blanford 1886; Gadgil and Iyengar 1980; Parthasarathy et al. 1993; Krishnamurti and Shukla 2000; Zubair and Ropelewski 2006).

In discussing the relation between the SWM and seasonal rainfall, precipitation in central parts of India, called the 
"Indian monsoon zone" (IMZ) (e.g., Sikka and Gadgil 1980; Gadgil 2003), has been assessed using Indian monsoon rainfall indices (e.g., All-India Rainfall: AIR, or the All-India Rainfall Index). These indices are based on the strong relationship of precipitation with the SWM (Fig. 2c). AIR is defined as an areal average of total precipitation based on rain gauge data for the summer monsoon months (JuneSeptember) in 29 selected subdivisions (Parthasarathy et al. 1994, 1995). According to previous studies based on AIR2, defined for the same areas as AIR, no significant trend was found for a recent 50-year interval (1951-2003) (Goswami et al. 2006; Rajeevan et al. 2006, 2010). Moreover, Goswami et al. (2006) highlighted that the contribution from increasingly frequent heavy rainfall events is offset by a decrease in frequency of moderate events.

Summer monsoon precipitation calculated in specific subdivisions over 135 years (1871-2005) was found to show an increasing trend in Punjab (northern India) and decreasing trends in parts of the northeastern states and Chhattisgarh (central India) (Kumar et al. 2010). Dash et al. (2007) noted a decreasing trend of summer monsoon precipitation in 10 meteorological subdivisions and an increasing trend in 12 subdivisions over the past century (1871-2002). They also reported seasonal difference in long-term precipitation trends, i.e., pre-monsoon and post-monsoon precipitation, averaged for all areas of India, has increased, whereas summer monsoon precipitation has decreased. These previous studies did not investigate the relation between the regionality of seasonal precipitation trends and atmospheric circulations.

Trends of weakening of the SWM over the Indian Ocean and of its effect on Indian summer monsoon rainfall have been mentioned in several recent papers (e.g., Joseph and Simon 2005; Naidu et al. 2009; Roxy et al. 2015; Karmakar et al. 2015, 2017). Joseph and Simon (2005) noted the LLJ of the active SWM weakened during 1950-2002. This weakening trend induced an increase in the duration of break (weak) monsoon spells and a decrease in the number of rainfall days. Roxy et al. (2015) reported a decreasing trend of summer monsoon rainfall around central India (i.e., the IMZ region) during 1901-2012, based on two gridded datasets from the Indian Meteorological Department (IMD) and the Climate Research Unit. They also suggested that a decrease of the land-sea thermal contrast due to sea surface temperature warming over the western Indian Ocean might have induced the decreasing trend of rainfall in central India.

The relation between monsoon variation and the mode of atmosphere-ocean interaction (e.g., El Niño-Southern Oscillation: ENSO) or the Indian Ocean Dipole mode is different for different seasons. Zubair and Ropelewski (2006) stated that the relationship between NEM rainfall and ENSO has not weakened, whereas the relationship between SWM rainfall and ENSO has weakened. The NEM rainfall has increased over a recent 30-year interval (1979-2010) in southeastern India, according to Prakash et al. (2013), who asserted that convective activity around the equatorial Indian Ocean is also increasing. As suggested by these results, the regionality of the long-term trend reflects a varied response of regional rainfall patterns related to changes in the atmospheric circulation of both the NEM and the SWM.

To analyze the relation between regional differences of long-term trends or interannual variations (IAVs) and atmospheric circulations in each season, a statistical method that separates the causes both spatially and temporally is needed. Many previous studies have adopted multiple classification, principal component, and cluster analyses to classify regional variability (e.g., Gadgil and Iyengar 1980; Kulkarani et al. 1992; Gadgil et al. 1993; Iyengar and Basak 1994; Azad et al. 2010; Satyanara and Srinivas 2011; Saikranthi et al. 2013; Kulkarni 2017). Such methods can classify regions depending on the characteristics of the long-term trend or IAV, or a multiple classification analysis such as empirical orthogonal function analysis or cluster analysis can be applied (e.g., Krishnamurti and Shukla 2000; Kulkarni 2017; Kakade and Kulkarni 2017). However, seasonal transitions of precipitation such as the amount of seasonal precipitation, amplitude of the annual precipitation cycle, and time of maximum precipitation are strongly dependent on region. The long-term trend and IAV of precipitation can be assumed affected by different aspects of atmospheric circulation.

Some previous studies have classified regions depending on the characteristics of the long-term trend or IAV but they have not considered the regionality of seasonal transitions of precipitation. It can be assumed that variation of the SWM or the NEM has considerable effect on precipitation trends. For example, on the southwestern coast of southern India, summer monsoon rainfall is strongly related to the strength of SWM flow during the summer monsoon season, whereas the NEM flow makes only a small contribution to precipitation during the post-monsoon or winter season. In contrast, the NEM flow contributes considerably to the post-monsoon or winter precipitation around southeastern India. Therefore, it can be assumed that precipitation seasonality in each region of India is largely dependent on large-scale atmospheric circulations such as the SWM or the NEM. If this assumption were true, the regional long-term trends or IAVs defined by seasonal characteristics could be considered reasonable reflections of the tendencies of atmospheric circulations.

In this study, we defined homogeneous regions based on pentad rainfall seasonality using a multiple-classification method. Homogeneous regions were defined as regions with similar climatological seasonality of rainfall. We then 
analyzed both the long-term trend and IAV of precipitation for each homogeneous region, and we investigated the relationships of these parameters with atmospheric circulations.

\section{Methods/Experimental}

This study used the fourth version of a gridded daily rainfall dataset produced by the IMD, called IMD4 (Pai et al. 2014). The gridded dataset was compiled using daily rainfall data recorded by rain gauges. The data were obtained not only from IMD observatory stations but also from many hydrometeorology, agrometeorology, and local government stations with varying periods of availability. The total number of stations used for the dataset was 6955 . The dataset covers the period 19012013, and the horizontal resolution of the grid is $0.25^{\circ}$.

For the regression analysis with the atmospheric fields, we used the Japanese 55-year reanalysis (JRA55) monthly mean dataset (Kobayashi et al. 2015) from 1958 to 2013, because a suitable dataset for the period before the 1950s was difficult to find. The horizontal resolution of this dataset is $1.25^{\circ}$. The zonal and meridional winds at $850 \mathrm{hPa}\left(U_{850}\right.$ and $\left.V_{850}\right)$ and specific humidity from the JRA55 were also used. Column-integrated water vapor flux $(W U, W V)$ and its divergence were also calculated based on the JRA55 dataset.

Using IMD4, we calculated a linear trend of seasonal precipitation over two periods: 1901-2013 and 19582013. Based on previous studies (e.g., Parthasarathy et al. 1994; Jain et al. 2013), the seasons for the calculation of seasonal precipitation were defined as follows: pre-monsoon (March-May: MAM), summer monsoon (June-September: JJAS), post-monsoon (October-December: OND), and winter (January and February: JF). In particular, the post-monsoon season was defined to consider the precipitation affected by the NEM (e.g., Singh and Sontakke 1999; Saikranthi et al. 2013; Prakash et al. 2013). The nonparametric Mann-Kendall rank test (Kendall 1938; Mann 1945) was used to assess the statistical significance of the long-term linear trends.

We used hierarchical cluster analysis (i.e., the Ward method) to determine the number of homogeneous regions and the Euclidean distance. The 73 pentads' mean precipitation for each grid cell for 1901-2013 was calculated. Then, these data were applied in the cluster analysis as the explanatory variable. After classification, the regional averaged precipitation was calculated for each region. Additionally, the regression coefficient of the time series of seasonal precipitation and its standard deviation (SD) were calculated for the two different periods (1901-2013 and 1958-2013).

To analyze the causes of the long-term trends and IAVs of seasonal precipitation, we calculated the trends of wind ( $u$ and $v$ components) at $850 \mathrm{hPa}$ and water vapor flux for 1958-2013 using the JRA55 dataset. To focus on IAV, we also calculated a detrended time series of regional averaged seasonal precipitation over 19582013. Detrended values were calculated by subtracting the linear trend from the original time series. Then, we calculated a regression coefficient between the detrended time series of seasonal precipitation in each region and a time series of zonal wind at $850 \mathrm{hPa}\left(U_{850}\right)$, or meridional wind at $850 \mathrm{hPa}\left(V_{850}\right)$ and water vapor flux ( $W U$ and $W V$ ). The Student's $t$ test was used to ensure statistical significance of the value. The distribution of wind vectors at $850 \mathrm{hPa}$ is suitable to define the LLJ of the SWM and the NEM (e.g., Joseph and Simon 2005; George et al. 2011).

\section{Results and discussion}

Regionality of long-term trends of seasonal precipitation The long-term trend of precipitation in India over 113 years (1901-2013) is shown in Fig. 1a-d. The distribution of the annual precipitation trend (figure not shown) was found almost the same as the distribution shown in Fig. 1b. The northern part of the Arabian Sea coast and the coast of the Bay of Bengal (BoB) showed significant increasing trends (5\% significance level) of summer monsoon precipitation (JJAS) (Fig. 1b). The rate of increase of rainfall was $>5 \mathrm{~mm} \mathrm{year}^{-1}$ for the Arabian Sea coast. A significant decreasing trend was observed in the IMZ region and along the southern part of the Arabian Sea coast, as reported by Roxy et al. (2015). The IMZ region and the southern part of the Arabian Sea coast also showed a decreasing trend for the winter (JF) season with a rate of $0-2 \mathrm{~mm}$ year $^{-1}$ (Fig. 1d). A new finding of this study was a decreasing trend of rainfall around central and eastern India observed not only during JJAS but also in JF.

For the other seasons, a weak $\left(<1 \mathrm{~mm}\right.$ year $\left.^{-1}\right)$ decreasing trend was observed in western to central India for the pre-monsoon (MAM) and winter (JF) seasons (Fig. 1a, d). There was also a weak decreasing trend of JF precipitation in the northeastern states (Fig. 1d). Precipitation in the post-monsoon season (OND) showed no significant trend of increase or decrease, except in small areas (Fig. 1c).

We also analyzed the trend of seasonal precipitation during 1958-2013 (56 years; middle term) for comparison (Fig. 1e-h). A significant decreasing trend in JJAS and OND precipitation was observed in the northern part of India (Fig. 1f, g). A significant increasing trend of JJAS precipitation was found over part of the Arabian Sea coast, the coast of the BoB, and part of northeastern India (Fig. 1f). In contrast, the northern part of the Arabian Sea coast showed a weak decreasing trend in the MAM season (Fig. 1e). For the winter (JF) season, a weak trend was observed over a broad area in terms of 


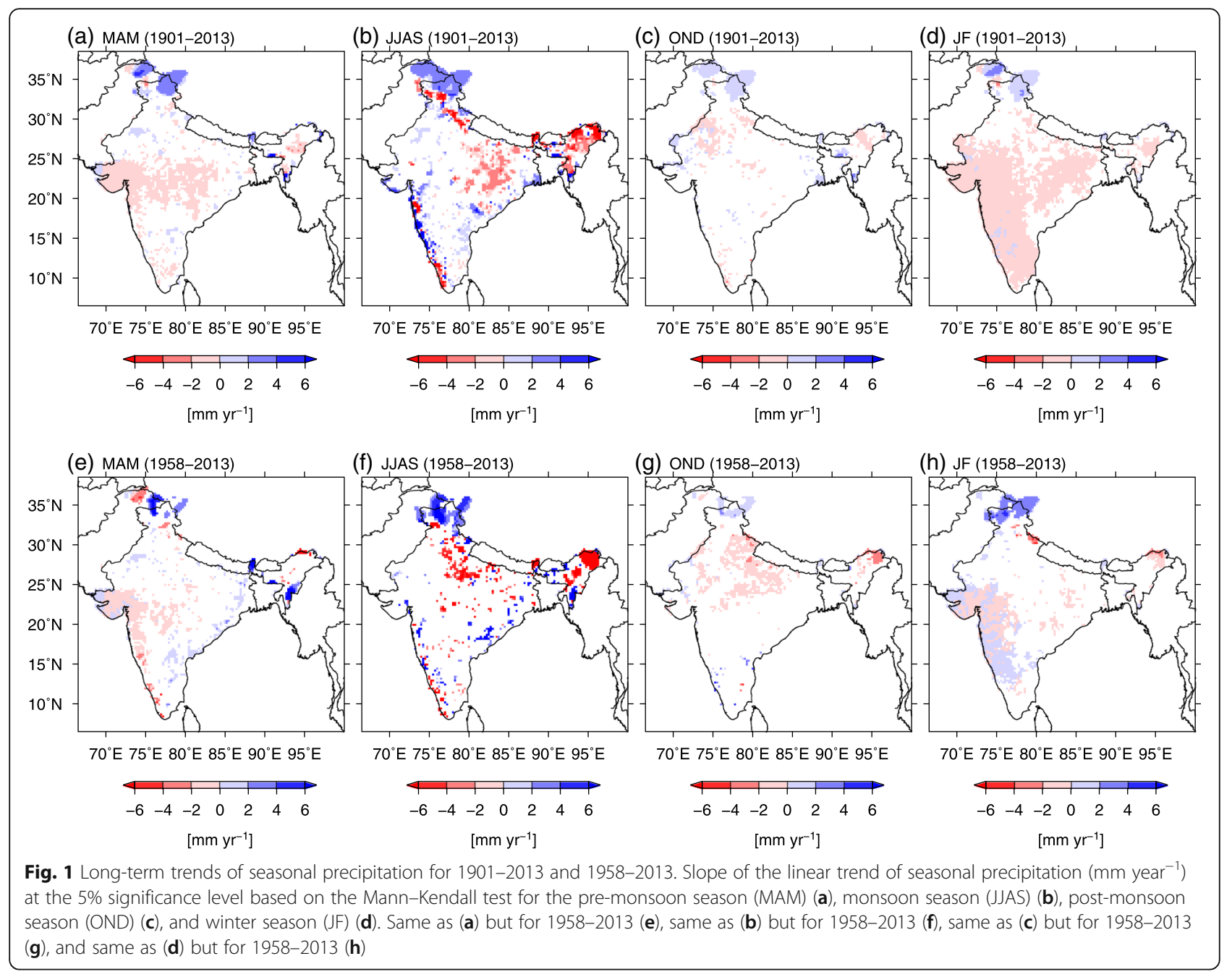

the long-term trend (Fig. 1d); however, this trend was observed only around the western coastal region in the middle term (Fig. 1h).

Comparison of the trends of summer monsoon precipitation between the 113-year and 56-year periods revealed decreasing trends over the southwestern coast and northern India and increasing trends over the Arabian Sea coast and part of the BoB coast of southern India in both periods. In contrast, a decreasing trend in the IMZ region was found statistically significant only for the long-term (113-year) period.

Some significant increasing trends were observed for OND precipitation in small regions of northern, western, and eastern India for the period 1901-2013. A decreasing trend was observed around the Indo-Gangetic Plain in northern India during 1958-2013. Prakash et al. (2013) reported an increasing trend of rainfall (that can be defined as NEM rainfall) in areas affected by the NEM (i.e., the states of Tamil Nadu, Kerala, Karnataka, and Andhra Pradesh) based on data from 1979 to 2010.
However, our results showed an increasing trend in a few grids during 1958-2013.

\section{Regional characteristics of seasonal rainfall patterns in India and their relations with secular variations}

We conducted hierarchical cluster analysis to analyze the regional characteristics of the seasonal rainfall patterns. Averaged 73-pentad precipitation data for 113 years (1901-2013) were calculated for each grid cell and applied in the cluster analysis. A cutoff point was established for seven of the clusters because the Euclidean distance changed abruptly (Fig. 2b). These seven clusters are shown in the map in Fig. 2a. We defined these clusters as seven regions. The smallest region was cluster 6 (CL6) with 106 grid cells and the largest was cluster 3 (CL3) with 1561 grid cells.

The geographical extent of each cluster was as follows (Fig. 2a). Cluster 1 (CL1) was mainly within northwestern India. CL2 was located in the northern half of southern India. CL3 was located in central and eastern India, 


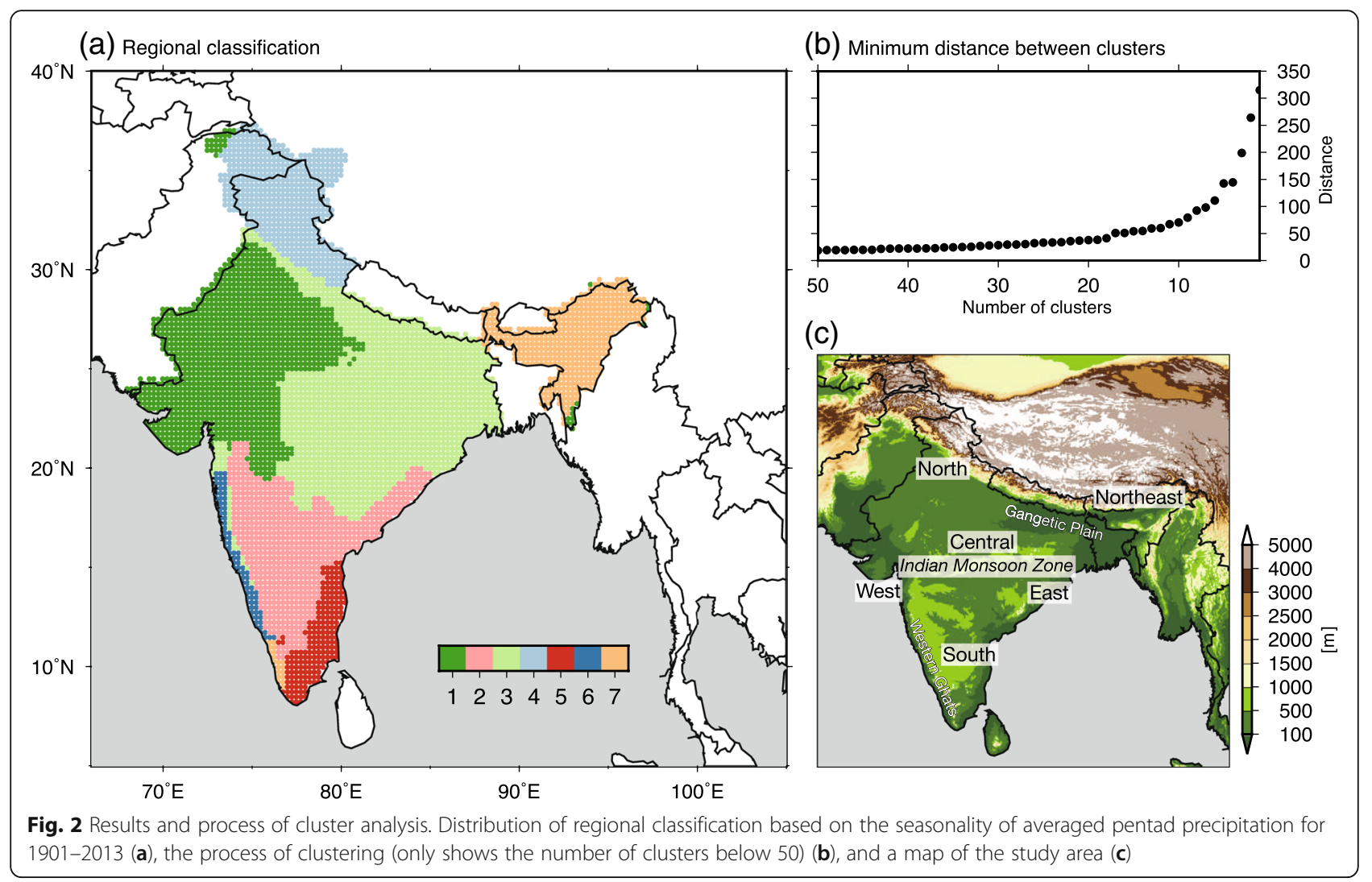

but it also included part of the western coast. Parts of the regions of CL1 and CL3 overlap the IMZ. CL4 was located in the western Himalayan region of northern India. CL5 was located along the eastern coastal region of southern India. CL6 was located along the western coast of the Arabian Sea in southern India. CL7 was defined as northeastern India and part of the western coastal region of southern India.

The seasonality of pentad-mean precipitation for each cluster is shown in Fig. 3. The summer rainy season can be seen in all clusters around pentad number 33 (P33) (10-14 Jun) to P50 (3-7 Sept). The largest peaks of the pentad rainfall in CL1, CL3, CL4, CL6, and CL7 were observed in the summer monsoon season (Fig. 3a, c, d, f, g). In the coastal area of the Arabian Sea (CL6), rapid onset of the summer monsoon with heavy rainfall was observed (Fig. 3f). This phenomenon reflects a characteristic of the SWM in the coastal region of the Arabian Sea (e.g., Ananthakrishnan and Soman 1988). Rainfall of over $100 \mathrm{~mm}$ pentad $^{-1}$ was observed from P33 (10-14 Jun) to P47 (19-23 Aug) with two peaks of maximum rainfall in P37 (30 Jun-4 Jul) and P40 (15-19 Jul).

In CL5, the post-monsoon rainy season dominated from P50 to P73 (27-31 Dec) (Fig. 3e). An effect of the NEM on precipitation can be detected in this region. The amount of post-monsoon rainfall in CL5 was approximately one-fifth the summer monsoon precipitation in CL6. Region CL2 (adjacent to region CL5) also experienced rainfall after the summer monsoon season (Fig. 3b) with a peak appearing in the post-monsoon season around P53 (18-22 Sep). Pre-monsoon rainfall was also observed in these two regions. Tropical cyclones might contribute to this rainfall (e.g., Wahiduzzaman et al. 2017).

A small amount of rainfall of around $10-15 \mathrm{~mm}_{\text {pentad }}{ }^{-1}$ occurred from P70 (12-16 Dec) to the beginning of the monsoon season in the foothills of the western Himalayas (CL4) (Fig. 3d). It included rainfall of the pre-monsoon season from around P15 (12-16 Mar) to P30 (26-30 May). Both CL4 and CL7 experienced pre-monsoon rainfall (Fig. 3 g). In particular, pre-monsoon rainfall in CL7 was around $15-50 \mathrm{~mm}$ pentad ${ }^{-1}$. Substantial contribution to annual precipitation by seasonal precipitation during winter (JF) to the pre-monsoon season in the foothills of the Himalayas (including Nepal) has also been reported (Yadav et al. 2007; Fukushima and Takahashi 2012a). Mid-latitudinal disturbances called western disturbances contribute greatly to precipitation in this area (e.g., Lang and Barros 2004).

Given the above results, we observe the following relations between regional rainfall characteristics and atmospheric circulations: 
(a) $C L 1$ ( $G=1297)$

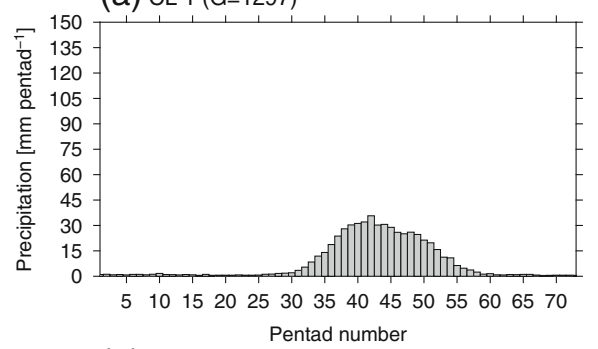

(b) $C L 2$ ( $G=728)$

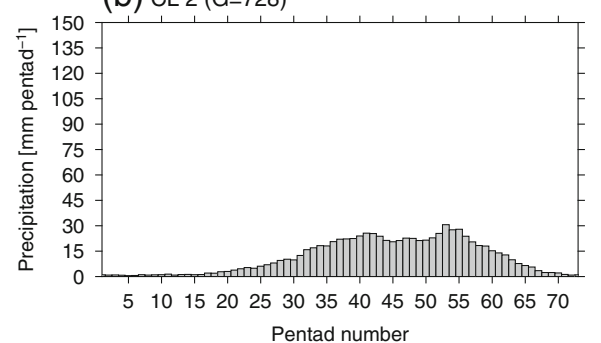

(c) $\mathrm{CL} 3(\mathrm{G}=1561)$

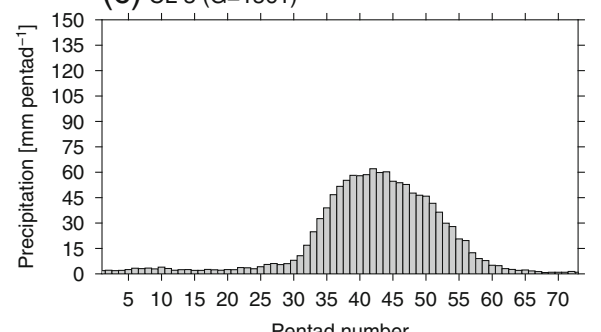

(d) $C L 4$ ( $G=570)$

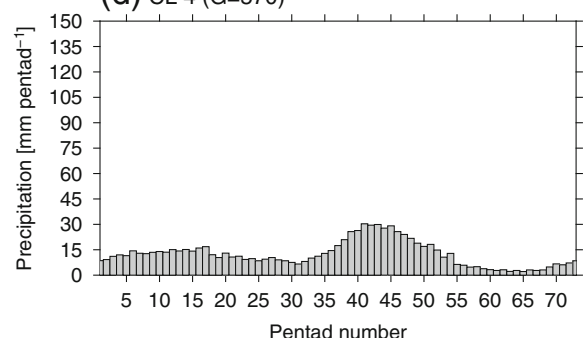

(e) $C L 5$ (G=201)

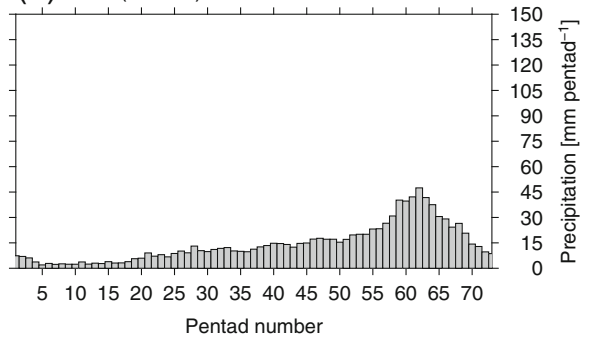

(f) $C L 6$ (G=106)

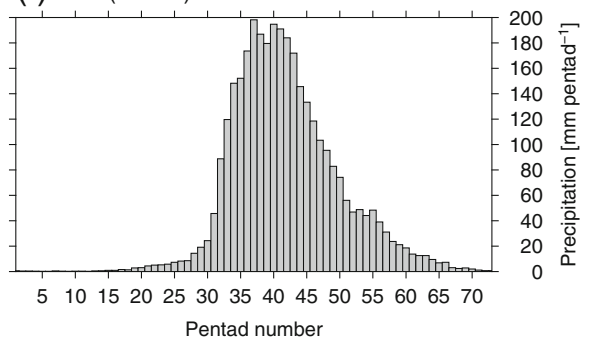

(g) $C L 7$ (G=491)

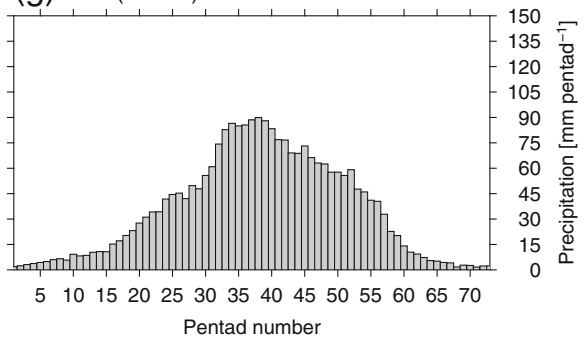

Fig. 3 Seasonality of the pentad-mean precipitation for each cluster. The pentad-mean precipitation averaged for 1901-2013 in CL1 (a), CL2 (b), CL3 $(\mathbf{c}), C L 4(\mathbf{d}), C L 5(\mathbf{e}), C L 6(\mathbf{f})$, and CL7 $(\mathbf{g})$. Horizontal axis represents pentad number $(\mathrm{P})$ for the year

1. Regions CL1, CL3, and CL6 receive rainfall mainly from the SWM.

2. Rainfall in CL5 reflects well the activity of the NEM, but continuous rainfall from the premonsoon to summer monsoon seasons is also shown for this region.

3. CL4 and CL7 receive rainfall unrelated to monsoonal flow (SWM or NEM) during the premonsoon and post-monsoon seasons, although the main rainy season corresponds to the summer monsoon season.

4. Regions CL2 and CL5 also receive pre-monsoon and post-monsoon rainfall.
In addition, we calculated the correlation coefficients of the time series of seasonal precipitation between the regional averaged values for each cluster and each grid cell (shown in the Additional file 1). The time series of seasonal precipitation correlated well with nearby regions. The tendency can be applied equally not only for JJAS but also for other seasons (figure not shown). Strong regional dependency can be considered to exist for the secular variation or the amounts of seasonal rainfall in India. In particular, CL2, CL5, and CL7 showed strong correlation with rainfall variations over their respective grid cells. These results imply that the secular variation of seasonal precipitation in these regions has 
strong regional dependency. In contrast, CL1, CL3, and CL6 showed distributions of the correlation coefficient that were similar to each other, except during the winter (JF) season. Thus, the secular variations of seasonal rainfall in these three regions are linked, except in winter.

According to these results, the regions defined in this study can be considered to represent not only the regionality of seasonal precipitation but also the regionality of secular variation of seasonal rainfall. We performed regression analysis to evaluate the relationship between regionality and atmospheric circulations.

\section{Long-term and middle-term trends of seasonal precipitation for each cluster}

The long-term trends of seasonal precipitation for the periods of 113 years (1901-2013; hereafter, long term) and 56 years (1958-2013; hereafter, middle term) are presented in Tables 1 and 2 and Figs. 4 and 5. It can be seen that the SDs of seasonal precipitation do not change between the two periods for all clusters and seasons (Tables 1 and 2). Significant increasing trends of JJAS precipitation can be seen in CL4 and CL6 for the long term, as well as in CL4 for the middle term (Table 1 and Fig. $4 \mathrm{~d}, \mathrm{f}$ ). The increasing rate of JJAS precipitation in CL6 was $2.96 \mathrm{~mm}^{-1}$ year $^{-1}$ for the 113-year period but only $0.58 \mathrm{~mm} \mathrm{year}^{-1}$ for the 56 -year period. Despite noticeable increase in precipitation in CL6 during the 1950s-1960s, no dominant signal was observed after the 1960s (Fig. 4f). Kumar et al. (2010) investigated the period 1871-2005 (135 years) and they reported a trend of increase of monsoon precipitation for the coast of the Arabian Sea (coastal Karnataka subdivision) of 1.5$1.8 \mathrm{~mm}$ year $^{-1}$. Their trend of increase is consistent with our findings but the value of the slope here is larger than found in the previous study.

Only the JJAS precipitation in CL7 showed a significant decreasing trend in the middle term. This result is consistent with Deka et al. (2013). They mentioned a significant decreasing trend of summer monsoon precipitation during the 30-year period of 1981-2010 over the Brahmaputra and Barak basins in Assam state (Northeast India). Region CL3 showed no significant trend, which is inconsistent with the results of Roxy et al. (2015) who reported a decreasing trend in the eastern part of the IMZ.

Regarding pre-monsoon (MAM) and post-monsoon (OND) precipitation, CL4 showed a significant increasing trend for the long-term period (Fig. 5d). No clusters showed any trends in the middle term for either season (Tables 1 and 2, Fig. 5). The OND precipitation in CL5 reflects the large IAV of the NEM with SD of about $150 \mathrm{~mm} \mathrm{year}{ }^{-1}$ (Tables 1 and 2). For the winter (JF) season, significant decreasing trends in CL3 and CL5 and an increasing trend in CL4 were found for the long-term period (Table 1, Fig. 5c, e). However, the SD of JF precipitation is nearly equal to the amount of JF precipitation in each region, and the effect of IAV for winter (JF) precipitation can be assumed large (Tables 1 and 2). The secular variation of seasonal precipitation showed large IAV in all regions (Figs. 4 and 5).

The next two sections analyze the variation of lower tropospheric circulations as related to seasonal precipitation to clarify the underlying causes. Hereafter, the data period of the analysis is 1958-2013 because of the availability of the JRA55 dataset.

\section{Middle-term trend of seasonal precipitation and low-level monsoonal flow}

The climatological distributions of summer (JJAS) precipitation and wind vectors at $850 \mathrm{hPa}$ are presented in Fig. 6b. The LLJ in the SWM flow is distributed as a strong westerly wind over the Indian Ocean around $0^{\circ}-20^{\circ} \mathrm{N}$ at $850 \mathrm{hPa}$ (e.g., Joseph and Simon 2005). JJAS precipitation exceeds $3000 \mathrm{~mm}$ in the southwestern coastal region. The second largest amount of JJAS precipitation occurs in the northeastern region. Precipitation of $500-1500 \mathrm{~mm}$ is observed in the central region (around $18^{\circ}-26^{\circ} \mathrm{N}, 76^{\circ}-88^{\circ}$ E). The wind in the lower troposphere over this IMZ area

Table 1 Regression coefficient of the long-term trend of seasonal precipitation on each cluster for 1901-2013

\begin{tabular}{|c|c|c|c|c|c|c|c|c|c|}
\hline & \multirow{3}{*}{$\begin{array}{l}\text { No. } \\
\text { of } \\
\text { Grid }\end{array}$} & \multicolumn{2}{|l|}{ MAM } & \multicolumn{2}{|l|}{ JJAS } & \multicolumn{2}{|l|}{ OND } & \multicolumn{2}{|l|}{$\mathrm{JF}$} \\
\hline & & \multicolumn{2}{|l|}{$1901-2013$} & \multicolumn{2}{|l|}{$1901-2013$} & \multicolumn{2}{|l|}{$1901-2013$} & \multicolumn{2}{|l|}{$1901-2013$} \\
\hline & & $\left(\mathrm{mm}\right.$ year $\left.^{-1}\right)$ & S.D. & $\left(m m\right.$ year $\left.^{-1}\right)$ & S.D. & $\left(m m\right.$ year $\left.^{-1}\right)$ & S.D. & $\left(\mathrm{mm}\right.$ year $\left.^{-1}\right)$ & S.D. \\
\hline$\overline{\mathrm{CL} 1}$ & 1297 & 0.02 & 12.33 & 0.47 & 115.77 & 0.03 & 22.25 & -0.04 & 8.58 \\
\hline $\mathrm{CL} 2$ & 728 & 0.00 & 28.76 & 0.53 & 99.88 & 0.08 & 58.92 & -0.05 & 10.02 \\
\hline CL3 & 1561 & -0.10 & 25.91 & -0.36 & 106.66 & -0.02 & 44.56 & -0.17 & 19.66 \\
\hline $\mathrm{CL} 4$ & 570 & 1.13 & 85.25 & 0.81 & 104.17 & 0.44 & 51.83 & 0.54 & 60.80 \\
\hline CL5 & 201 & 0.04 & 48.23 & 0.29 & 84.59 & -0.03 & 148.41 & -0.31 & 42.00 \\
\hline CL6 & 106 & 0.00 & 85.11 & 2.96 & 431.45 & 0.12 & 86.23 & -0.02 & 5.89 \\
\hline $\mathrm{CL} 7$ & 491 & 0.13 & 125.50 & -1.32 & 212.29 & 0.00 & 59.76 & -0.02 & 27.54 \\
\hline
\end{tabular}


Table 2 Regression coefficient of the long-term trend of seasonal precipitation on each cluster for 1958-2013

\begin{tabular}{|c|c|c|c|c|c|c|c|c|c|}
\hline & & MAM & & JJAS & & OND & & $\mathrm{JF}$ & \\
\hline & $\begin{array}{l}\text { of } \\
\text { Grid }\end{array}$ & 1958-2013 & & 1958-2013 & & 1958-2013 & & $1958-2013$ & \\
\hline & & $\left(\mathrm{mm}\right.$ year $\left.^{-1}\right)$ & S.D. & $\left(\mathrm{mm}\right.$ year $\left.^{-1}\right)$ & S.D. & $\left(\mathrm{mm}\right.$ year $\left.^{-1}\right)$ & S.D. & $\left(\mathrm{mm}\right.$ year $\left.^{-1}\right)$ & $\overline{\text { S.D. }}$ \\
\hline $\mathrm{CL1}$ & 1297 & 0.06 & 11.50 & -0.17 & 117.12 & -0.16 & 20.34 & 0.06 & 7.92 \\
\hline $\mathrm{CL} 2$ & 728 & 0.07 & 29.98 & 0.41 & 108.86 & 0.20 & 55.83 & 0.10 & 8.04 \\
\hline CL3 & 1561 & 0.10 & 23.00 & -0.27 & 112.58 & -0.20 & 40.71 & -0.06 & 15.09 \\
\hline$C L 4$ & 570 & 0.87 & 100.51 & 2.02 & 119.41 & 0.07 & 57.16 & 0.83 & 54.24 \\
\hline CL5 & 201 & 0.51 & 47.13 & 0.34 & 102.46 & 0.30 & 149.69 & 0.20 & 39.60 \\
\hline CL6 & 106 & -0.79 & 79.71 & 0.58 & 459.11 & 1.02 & 79.15 & 0.05 & 5.00 \\
\hline CL7 & 491 & 0.94 & 130.32 & -4.25 & 234.24 & -0.52 & 61.87 & -0.29 & 29.53 \\
\hline
\end{tabular}

Bold: Significant at $5 \%$

is weaker than south of $18^{\circ} \mathrm{N}$. The intraseasonal variability typified by the active-break cycle strongly influences this area (Lau and Waliser 2005). The IMZ and the foothills of the Himalayas are alternately affected by the active and break phases. When the area is in the active phase, rainfall is observed continuously. In contrast, no rainfall or only a small amount of rainfall is observed in the area during the break phase. This phenomenon is induced by a shift of the monsoon trough (equivalent to the intertropical convergence zone in the summer). The distribution of water vapor flux divergence reveals an area of strong convergence in the nearby southwestern coastal region of the Gangetic Plain (Plains of Hindustan) and the northeastern region (figure not shown). The water vapor sources for these regions are considered the Arabian Sea and BoB.

The regionality of rainfall distribution is different in other seasons. For example, the southeastern region received over $700 \mathrm{~mm}$ in the post-monsoon season (OND) (Fig. 6c). The observed OND rainfall was caused by NEM flow (with northeasterly flow around $15^{\circ}-20^{\circ} \mathrm{N}$ in the BoB) (e.g., George et al. 2011). Convergence of water vapor flux is evident in the southern part of the $\mathrm{BoB}$, near the southwestern region (figure not shown). For the pre-monsoon (MAM) season, 200-1000 mm of precipitation was observed around the Himalayas, in the northwestern and northeastern regions (Fig. 6a). Westerly winds dominate around the Himalayas in both the pre-monsoon season and the winter season. The westerly wind can be considered a separated flow of the subtropical jet stream (Fukushima and Takahashi 2012b). Strong divergence of water vapor flux was found over a broad area of the Arabian Sea and BoB (figure not shown).

Figure $6(\mathrm{e}-\mathrm{h})$ presents a middle-term trend of wind vectors at $850 \mathrm{hPa}$ for each season. The distribution for JJAS shows a significant increasing trend of southwesterly wind at $60^{\circ} \mathrm{E}$ and northwesterly wind at $80^{\circ} \mathrm{E}$, around the equator over the Indian Ocean (Fig. 6f). A northeasterly anomaly over the eastern fringe of Africa (around $15^{\circ} \mathrm{N}, 50^{\circ} \mathrm{E}$ ) indicates weakening of the cross-equatorial flow of the SWM in comparison with the climatological distribution (Fig. 6b, f). From these signals, a southeastward shift of the cross-equatorial flow of the SWM over the last 56 years can be inferred. In addition, a significant anomaly of westerly wind over the eastern part of the Indian Ocean and a significant decreasing anomaly of the convergence observed over the northern part of the Arabian Sea and the equatorial Indian Ocean can be interpreted to support this inference (figure not shown). However, despite the significant trend that appears in the lower troposphere over the ocean surrounding India, almost no significant trend in the low-level wind field could be seen over the Indian subcontinent in the summer monsoon season, apart from western, eastern, and southern coastal regions.

Weakening of the seasonal cross-equatorial flow near the equator over the Indian Ocean was also observed during the post-monsoon (OND) and winter (JF) seasons (Fig. 6g, h). Although an increase of water vapor divergence over the BoB was observed (figure not shown), this tendency has not influenced NEM flow over the BoB or the long-term trend of OND precipitation in region CL5 (Tables 1 and 2). Therefore, weakening of the cross-equatorial flow over the Indian Ocean during the post-monsoon season might not be related to the NEM trend.

Another interesting result is the signal of early onset of the SWM during the pre-monsoon season. Significant strengthening of the southwesterly wind is seen over the equatorial Indian Ocean around $40^{\circ}-60^{\circ} \mathrm{E}$ and $70^{\circ}-80^{\circ} \mathrm{E}$ (Fig. 6e). Moreover, there is weakening of the westerly wind around the northern Indian subcontinent. These tendencies imply an early shift of atmospheric conditions to the summer monsoon phase. Nonetheless, this shift did not affect the long-term precipitation trend. Moreover, a weak increase of water vapor flux around the Himalayan region (including Nepal) was detected in the pre-monsoon and 
(a) CL 1: JJAS

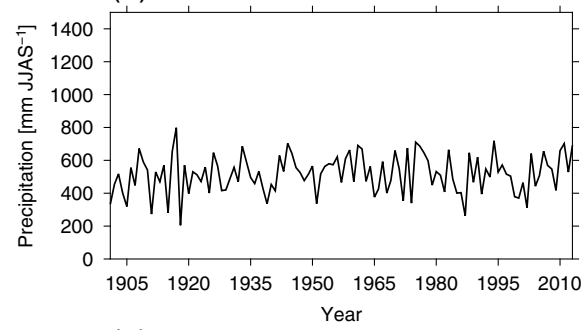

(b) CL 2: JJAS

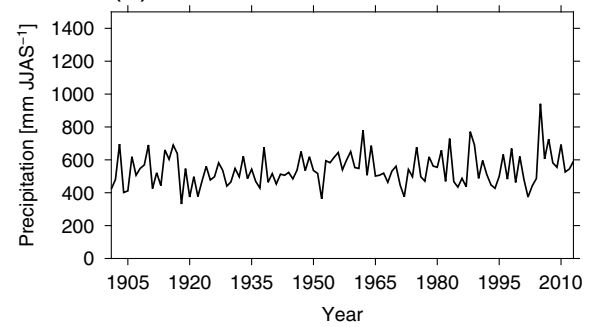

(c) CL 3: JJAS

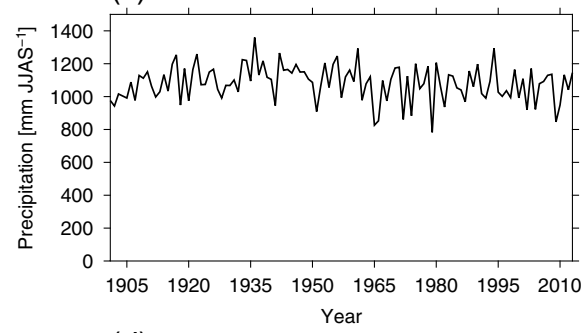

(d) CL 4: JJAS

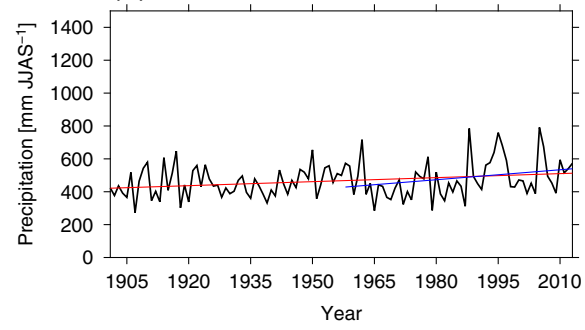

(e) CL 5: JJAS
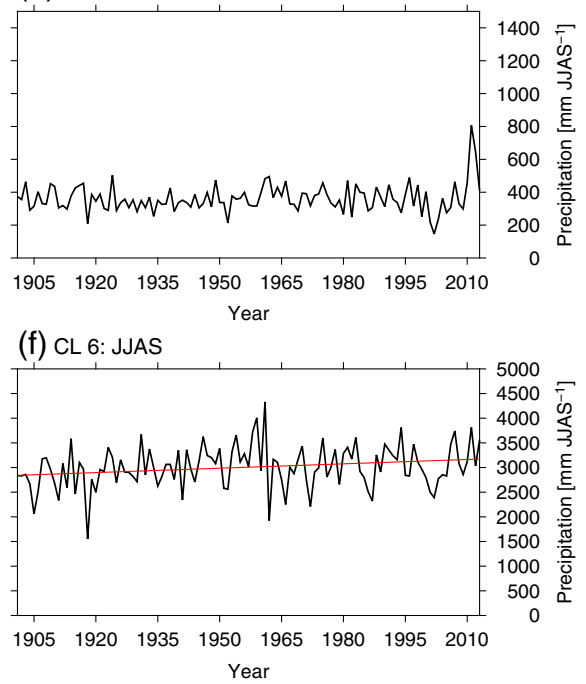

(g) CL 7: JJAS

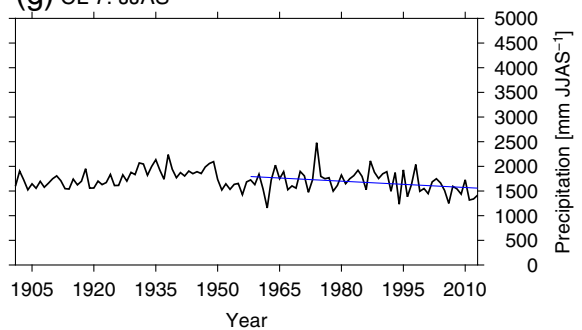

Fig. 4 Secular variation of summer monsoon precipitation for each cluster. Time series of JJAS precipitation averaged in CL1 (a), CL2 (b), CL3 (c), CL4 (d), CL5 (e), CL6 (f), and CL7 (g). The straight line shows the regression of the long-term trend at the 5\% significance level for 1901-2013 (red) and 1958-2013 (blue)

post-monsoon seasons (figure not shown). These results should be examined closely in future work.

\section{Relationship of IAV between precipitation and low-level monsoonal flow}

This section discusses the IAV relationship between seasonal precipitation and atmospheric circulation for the monsoon, post-monsoon, and pre-monsoon seasons. The results are presented as wind vector distributions ( $U_{850}$ and $V_{850} ; W U$ and $W V$ are combined) in Figs. 7, 8, 9, 10, 11, and 12. We selected three seasons (JJAS, OND, and MAM) and five clusters (CL2, CL3, CL5, CL6, and CL7) to analyze the regionality of the relationship between seasonal precipitation and atmospheric circulation.

From the regression coefficient distribution for CL3, a strong and statistically significant relation between the southwesterly anomaly over the southern Arabian Sea and JJAS precipitation can be seen $\left(5-20^{\circ} \mathrm{N}, 50-75^{\circ} \mathrm{E}\right)$ in Fig. 7b. In particular, cross-equatorial flow, which strengthens the SWM flow, is found mainly over the western part of the Indian Ocean. The southwesterly flow is also related to IAV in CL6 but the location of the cross-equatorial flow is shifted slightly eastward $\left(60^{\circ}-80^{\circ}\right.$ E) (Fig. 7d). Another similarity between regions CL3 and CL6 is an anomaly of the southeasterly wind around the Gangetic Plain. This southeasterly flow might be related 
(a) CL 1: MAM, OND \& JF

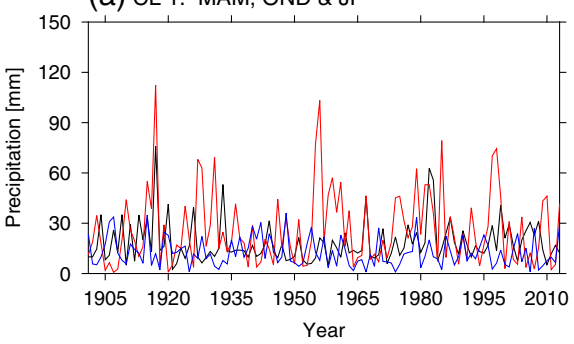

(b) CL 2: MAM, OND \& JF

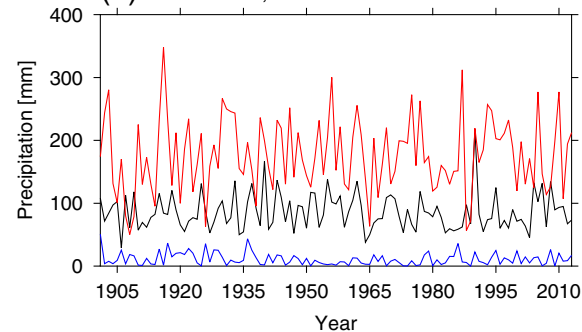

(c) CL 3: MAM, OND \& JF

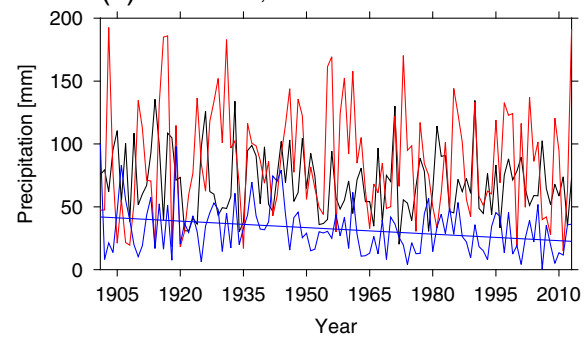

(d) CL 4: MAM, OND \& JF

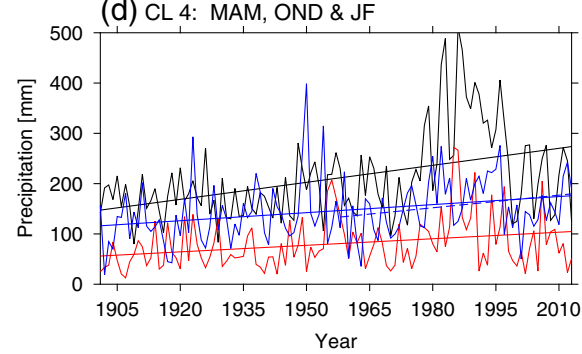

(e) CL 5: MAM, OND \& JF

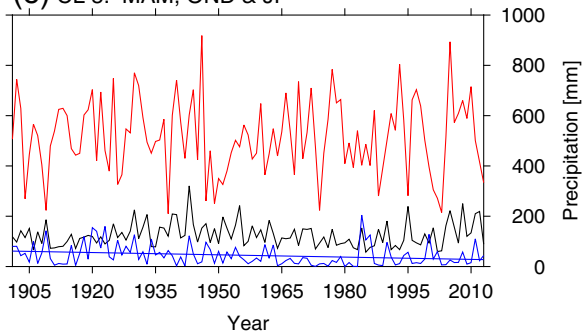

(f) CL 6: MAM, OND \& JF

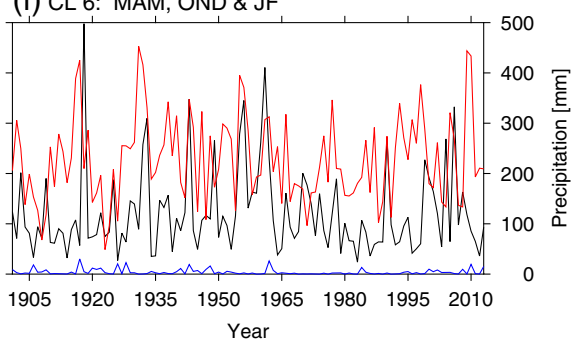

(g) CL 7: MAM, OND \& JF

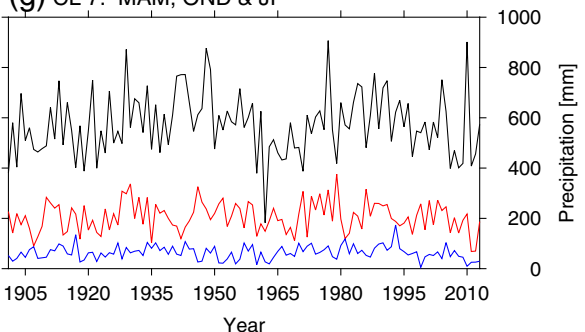

\begin{tabular}{l} 
Z: MAM \\
Z: OND \\
\hline
\end{tabular}

Fig. 5 Secular variation of pre-monsoon (MAM), post-monsoon (OND), and winter precipitation (JF) for each cluster. Time series of MAM (black), OND (red), and JF (blue) precipitation averaged in CL1 (a), CL2 (b), CL3 (c), CL4 (d), CL5 (e), CL6 (f), and CL7 (g). The straight line shows the regression of the long-term trend at the 5\% significance level for 1901-2013 (solid) and 1958-2013 (dashed)

to activity of the monsoon trough (e.g., Pant and Kumar Rupa 1997). Furthermore, an anomaly of water vapor flux convergence in the area over the Gangetic Plain is positively related to the JJAS rainfall in CL3 and CL6 (Fig. 8b, d).

The positive anomaly of the southwesterly water vapor flux over the equatorial Indian Ocean around $40^{\circ}-80^{\circ} \mathrm{E}$ is related to the IAV of JJAS precipitation in all regions except CL7 (Fig. 8a-d). In particular, the positive variations of precipitation in CL2 and CL5 are related to the increase of water vapor flux convergence over part of the Arabian Sea (around $5^{\circ}-10^{\circ} \mathrm{N}, 60^{\circ}-80^{\circ} \mathrm{E}$ ). Additionally, southerly or southeasterly anomalies around central India (around $20^{\circ} \mathrm{N}, 80^{\circ} \mathrm{E}$ ) from the $\mathrm{BoB}$ are related to positive rainfall variations in CL2, CL5, and CL7 (Fig. 8a, c, e).

The middle-term trend of the wind vector at $850 \mathrm{hPa}$ shows a suppressed anomaly of the SWM around the western part of the Arabian Sea (Fig. 6f). However, the trend is not affected in regions CL3 and CL6 because strong southwesterly flow exists over the Arabian Sea, accompanied by cross-equatorial flow. In particular, the easterly shift of the SWM flow favors an increase of rainfall in CL6 (Fig. 7d).

The strength of the westerly anomaly around the foothills of the Himalayas positively affects JJAS precipitation in the northeastern region (Fig. 7e). The westerly anomaly around the Himalayas is observed related only 


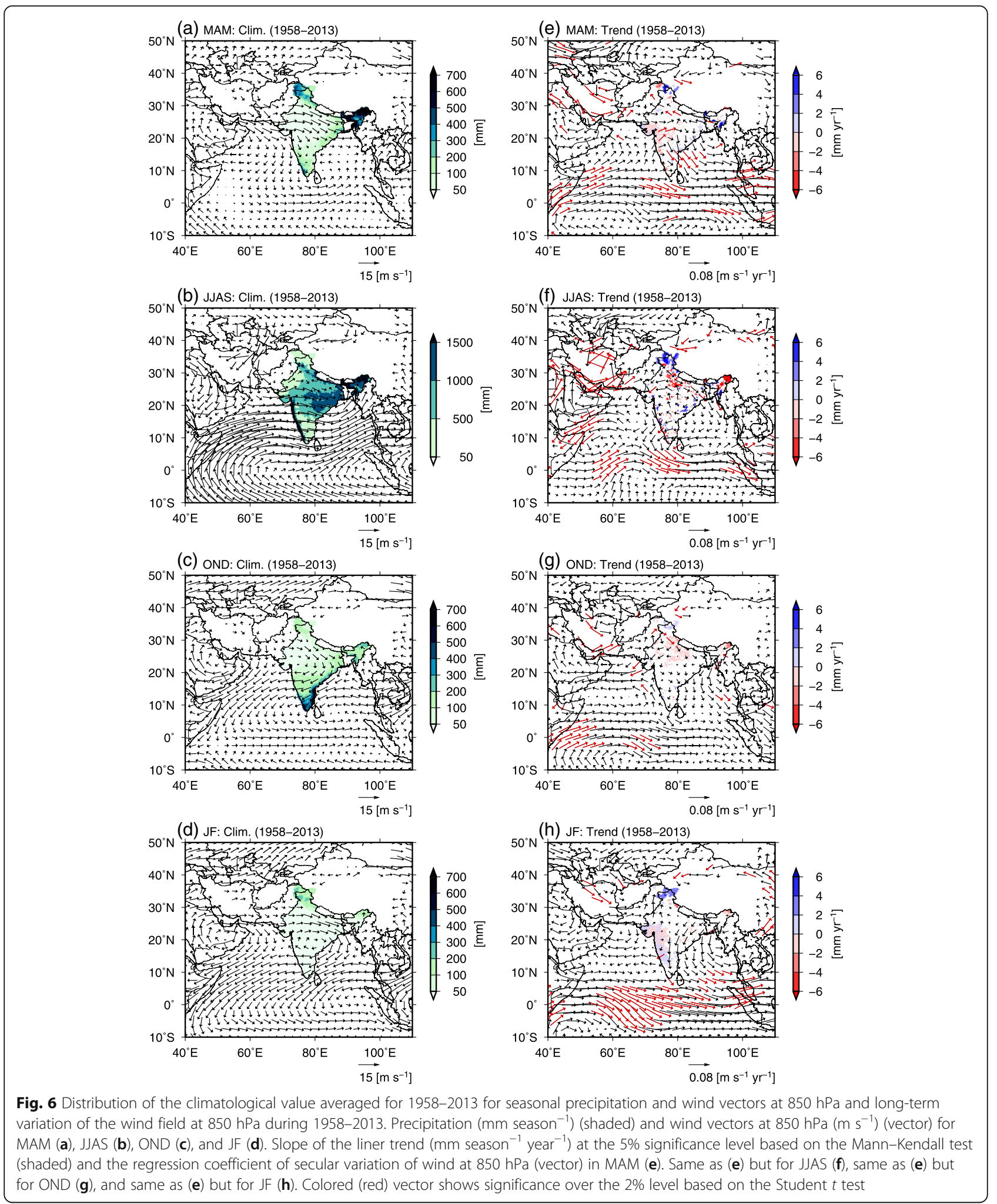

to region CL7. The middle-term trend in atmospheric circulation shows a northerly or northeasterly anomaly of wind around the region (Fig. 6f). This anomaly induces the suppression of precipitation. In fact, the middle-term trend of the JJAS precipitation in CL7 shows a significant decreasing trend. This result implies that the favorable circulation pattern for positive IAV in CL7 has decreased over the recent 58-year period. 
For the post-monsoon (OND) seasons, a southeasterly anomaly over the $\mathrm{BoB}$ is related to increased precipitation in CL5 (Fig. 9c). This tendency might strengthen the NEM wind around the region because a northeasterly flow is climatologically predominant over the BoB and Arabian Sea (Fig. 6c). A southeasterly anomaly of water vapor flux, which is defined by a wind orthogonal to the coast, and convergence of water vapor flux are positively related to CL5 rainfall from the middle of the subcontinent to the southeast coast (Fig. 10c).

A wind anomaly oriented orthogonally to the coastline accompanying water vapor flux convergence is related to the positive anomaly of the OND rainfall in CL2, CL3, and CL6 (Figs. 9a, b, d and 10a, b, d). These results imply that rainfall variability in this area is controlled largely by wind direction. In addition, when a regressed anomaly of the southwesterly flow suppresses the northeasterly flow over the northern Indian Ocean, OND precipitation in regions CL2, CL3, and CL6 is increased (Fig. 9a, b, d). Because of the inclusion of the transition season from the SWM to NEM, the IAV of SWM flow is considered to influence rainfall variation in the post-monsoon season. The middle-term trend of the atmospheric circulations shows weakening of cross-equatorial flow over the Indian Ocean in the post-monsoon season (Fig. 6g). Although this tendency can affect the low-level wind flow and precipitation amount in CL5 (Figs. 9c and 10c), precipitation shows no significant change (Table 2). Therefore, the rainfall in this region can be attributed not only to the NEM but also to other causes, e.g., such as tropical cyclones, which might require further investigation.

The strong westerlies dominating the north of the Indian subcontinent in the pre-monsoon season and southwesterlies over the Indian Ocean are not established in the climatology (Figs. 6a and 11f). Therefore, a signal of earlier onset of the SWM over the western Arabian Sea around $10^{\circ} \mathrm{N}$ is related to MAM precipitation in all clusters except CL7 (Fig. 11a-d). In contrast, an anomalous southwesterly wind that is evident at the western fringe of the $\mathrm{BoB}$ is dominant throughout the inland area of the northeastern states, and it contributes to excess rainfall in region CL7 (Fig. 11e). This southwesterly anomaly indicates strengthening of the climatological flow that is dominant in this season over the region. Regarding the distribution of water vapor flux, the southwesterly wind transports water vapor over land from the BoB and it strongly induces water vapor flux convergence. This phenomenon generates strong water vapor convergence over the northeastern states of India, Bangladesh, and Bhutan, as well as parts of Myanmar and Nepal. Pre-monsoon rainfall phenomena have been examined in these surrounding countries (e.g., Fukushima and Takahashi 2012a). According to those findings, the IAV of MAM precipitation in these regions is assumed strongly correlated with water vapor transport from a surrounding region. In the winter (JF) season, only the Himalayan area (including the northeastern states) receives rainfall and the IAV is related closely to the westerly flow (figure not shown). However, the southwesterly flow over the BoB or the westerly flow around the Gangetic Plain indicates a suppressed trend in the atmospheric circulation over the middle term (Fig. 6e). The effect of this tendency was not detected in the MAM precipitation amount in region CL7.

\section{Conclusions}

We conducted three analyses in this study. First, we compared the long-term (1901-2013) and middle-term (19582013) trends of seasonal precipitation in India. Whereas the northern coast of the Arabian Sea showed a significant increasing trend (significance level 5\%) in summer monsoon precipitation (JJAS) only for the long term, part of the coast of the BoB showed a significant increasing trend for both periods. The rate of increase of rainfall was $>5 \mathrm{~mm}_{\text {year }}{ }^{-1}$ for the Arabian Sea coast. A decreasing trend of summer monsoon precipitation was observed around central and eastern India (around the IMZ) for the long term. However, the tendency of the middle-term trend was not statistically significant. In addition, the decreasing trend of precipitation in central and eastern India (around the IMZ) for the long term was also significant for the winter season (JF). A long-term trend of decrease of JF precipitation was found over a broad area of western to southern India. For the post-monsoon (OND) season, although no significant trend was observed for the period 1901-2013, an increasing trend was observed in a portion of the regions for the period 1958-2013. Therefore, NEM activity is assumed to have changed recently over a short-term scale.

Next, we conducted hierarchical cluster analysis to classify homogeneous regions based on seasonal rainfall patterns (pentad precipitation). The seven obtained regions represented well the characteristics of the seasonal change of atmospheric circulations, such as summer and winter monsoons, as follows:

1. Regions CL1 (northern and western India), CL3 (central and eastern India), and CL6 (western coast of the Arabian Sea in southern India) received rainfall largely from the SWM.

2. Rainfall in CL5 (eastern coastal region of southern India) reflected well the activity of the NEM.

3. Regions CL4 (western Himalayan region in northern India) and CL7 (northeastern India and the eastern coastal region of southern India) received rainfall without any relation with monsoonal flow (SWM or NEM) during the premonsoon and winter (JF) seasons.

4. Regions CL2 (northern half of southern India) and CL5 received pre-monsoon and post-monsoon rainfall. 


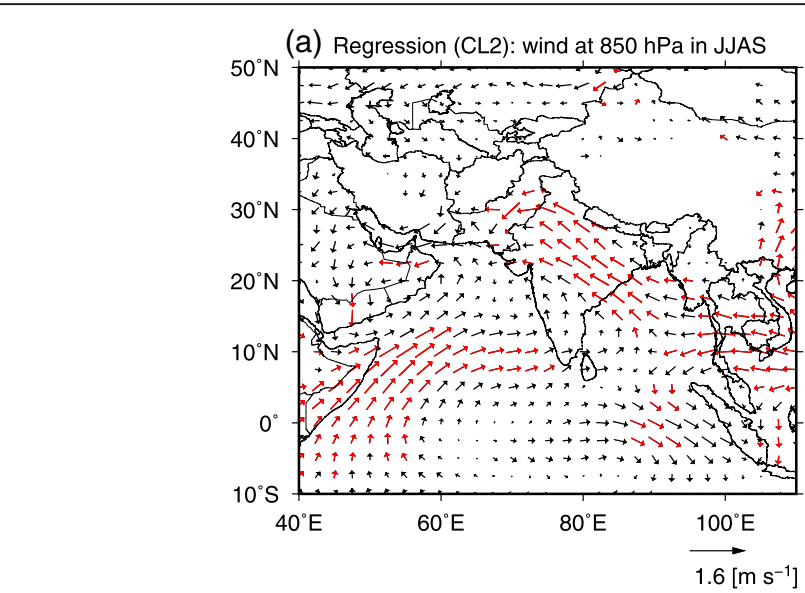

(d) Regression (CL6): wind at $850 \mathrm{hPa}$ in JJAS

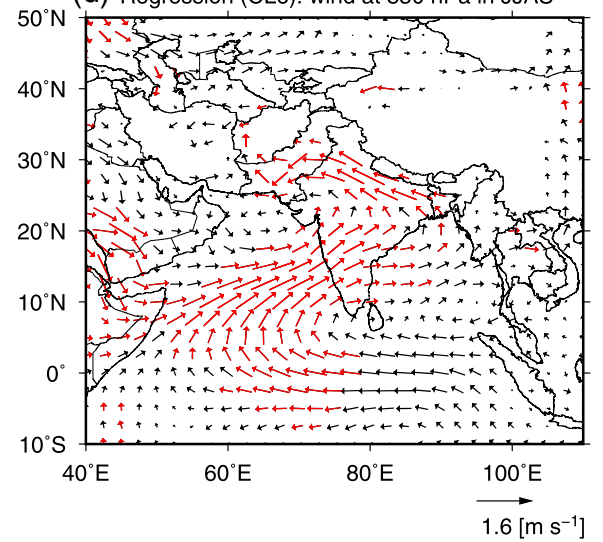

(e) Regression (CL7): wind at $850 \mathrm{hPa}$ in JJAS

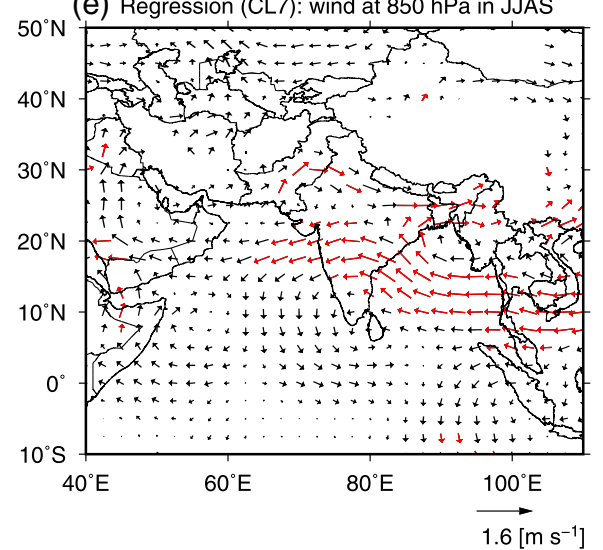

(f) Clim. in JJAS (1958-2013)

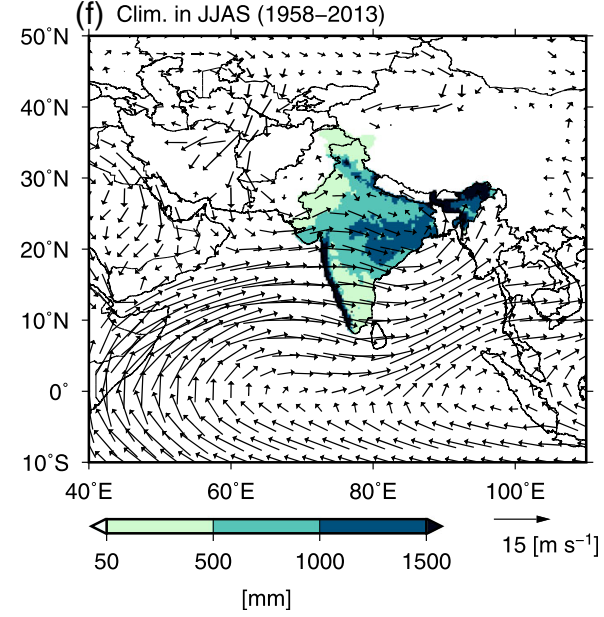

Fig. 7 Regression coefficient of rainfall and wind for the summer monsoon season. The regression coefficient (objective variable is precipitation) between interannual variation of rainfall and the wind field at $850 \mathrm{hPa}\left(\mathrm{m} \mathrm{s}^{-1}\right)$ (vector) for each cluster (a)-(e), and the distribution of the climatological values (averaged for 1958-2013) of seasonal precipitation and wind vectors at $850 \mathrm{hPa}$, as in Fig. 6b (f). Colored (red) vector shows significance over the $2 \%$ level based on the Student $t$-test

Using this regional classification, we analyzed the long-term and middle-term trends of seasonal precipitation for each cluster. For the summer monsoon season, CL6 and CL4 showed significant increasing trends for the long term, and CL7 showed a significant decreasing trend for the middle term. However, the pre-monsoon and the post-monsoon seasons had no obvious trends except in CL4. These results 


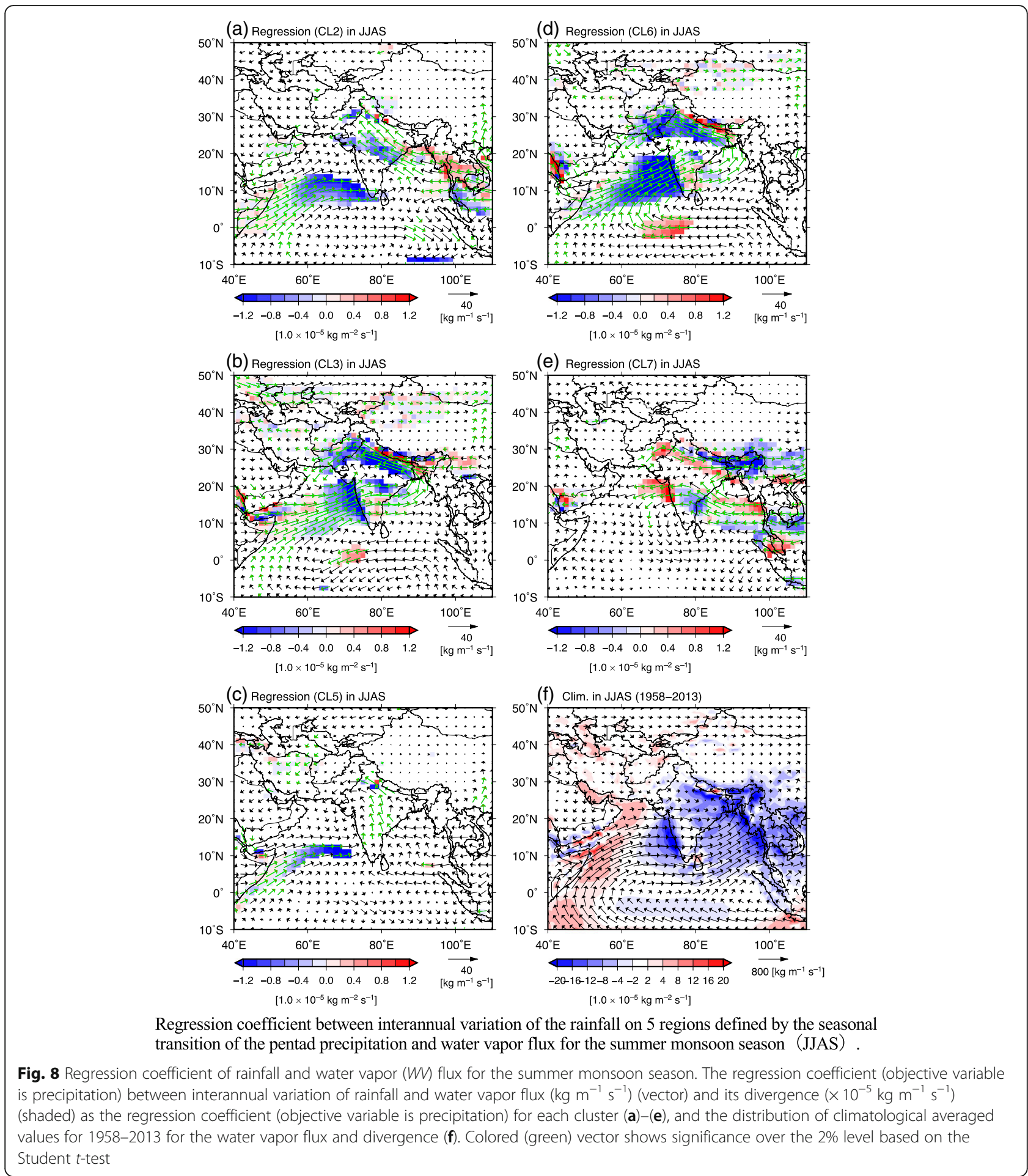

imply that the effects of IAV in seasonal precipitation are greater than the long-term trends for each cluster.

Next, we investigated the relations between the middle -term trend and atmospheric circulation patterns in the lower troposphere. Although a southerly and easterly shift of the cross-equatorial flow of the SWM was found to show a significant trend over the ocean surrounding India, no significant trend in the low-level wind field could be detected over the Indian subcontinent during summer. Weakening of the seasonal cross-equatorial flow near the equator over the Indian Ocean was also observed during the post-monsoon and winter (JF) seasons. Although an increase of water vapor divergence 


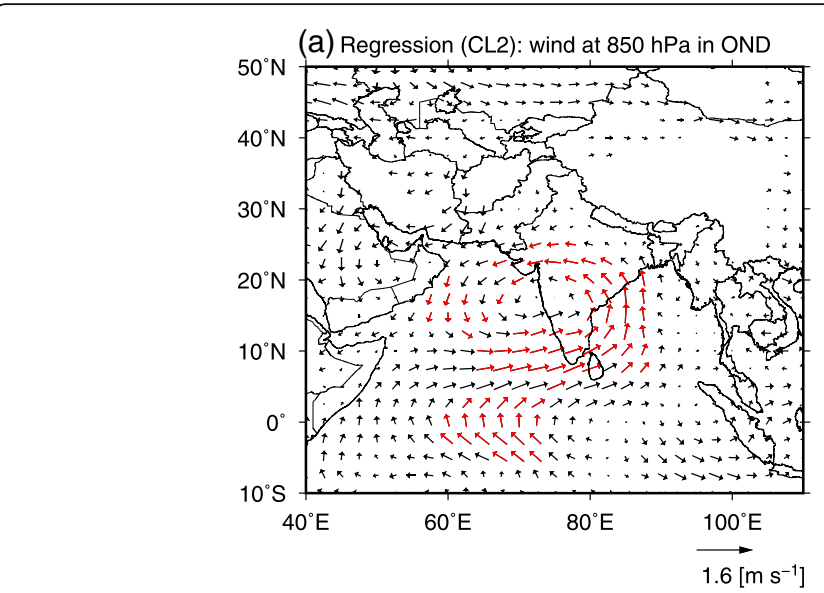

(d) Regression (CL6): wind at $850 \mathrm{hPa}$ in OND

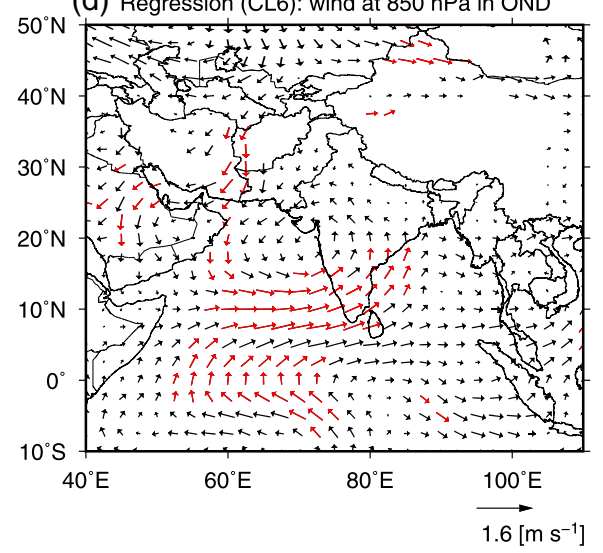

(b) Regression (CL3): wind at $850 \mathrm{hPa}$ in OND

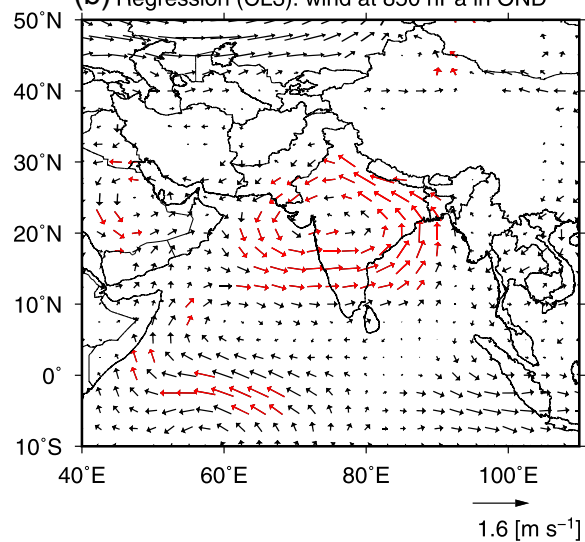

(e) Regression (CL7): wind at $850 \mathrm{hPa}$ in OND

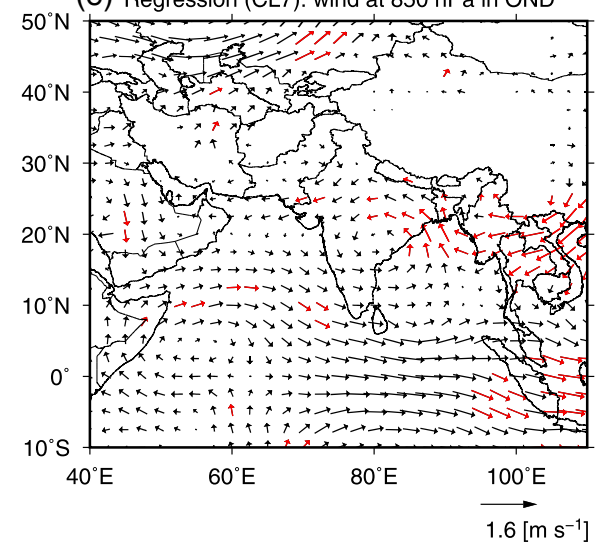

(c) Regression (CL5): wind at $850 \mathrm{hPa}$ in OND
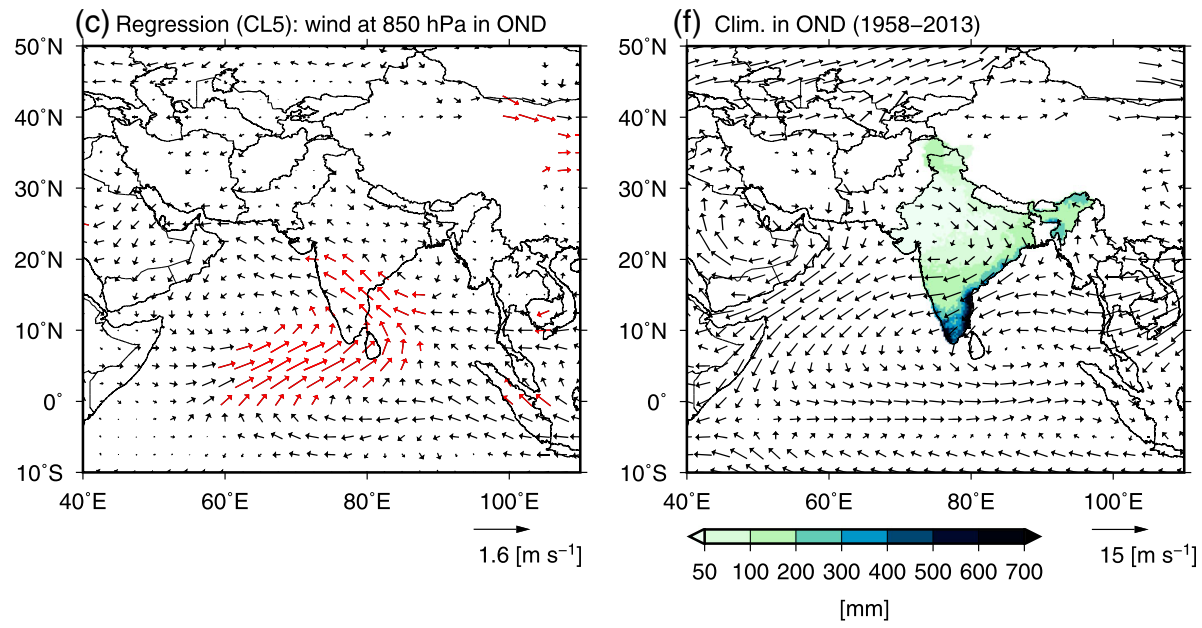

Fig. 9 Same as Fig. 7 but for the post-monsoon season (OND) The regression coefficient (objective variable is precipitation) between interannual variation of rainfall and the wind field at $850 \mathrm{hPa}\left(\mathrm{m} \mathrm{s}^{-1}\right)$ (vector) for each cluster (a)-(e), and the distribution of the climatological values (averaged for 1958-2013) of seasonal precipitation and wind vectors at $850 \mathrm{hPa}$, as in Fig. 6c (f)

over the BoB was observed, this tendency has not influenced NEM flow over the BoB or the long-term trend of OND precipitation in region CL5. Consequently, long-term change of atmospheric circulation over the ocean surrounding India was detected for each season but it can be considered not to affect the trend of seasonal precipitation for each cluster.

Finally, we investigated the relation of the IAV between seasonal precipitation and atmospheric circulations. Enhancement of the southwesterly flow over the Indian 

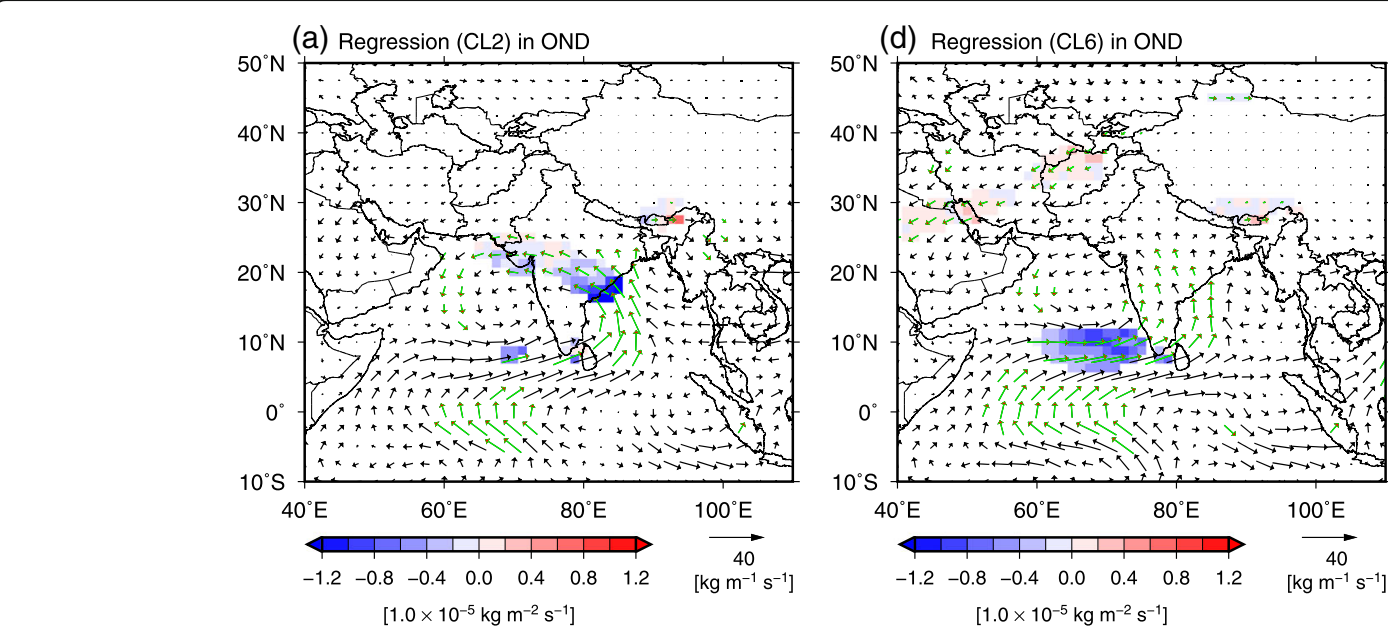

(b) Regression (CL3) in OND

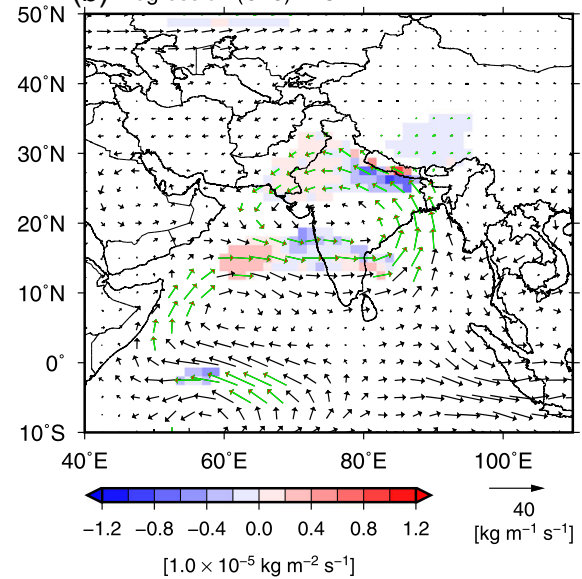

(e) Regression (CL7) in OND

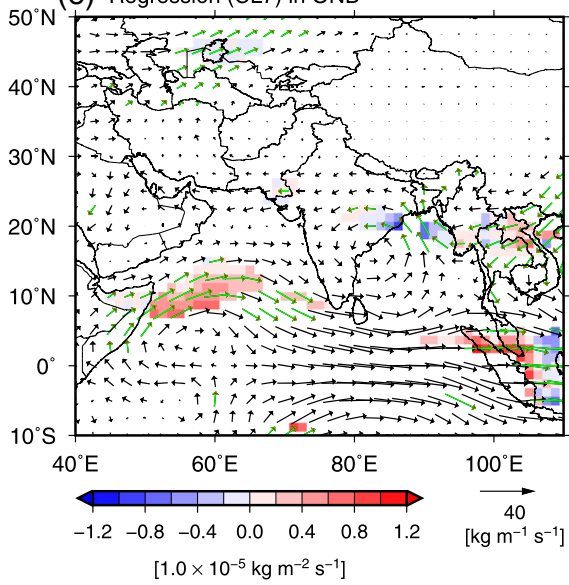

(c) Regression (CL5) in OND
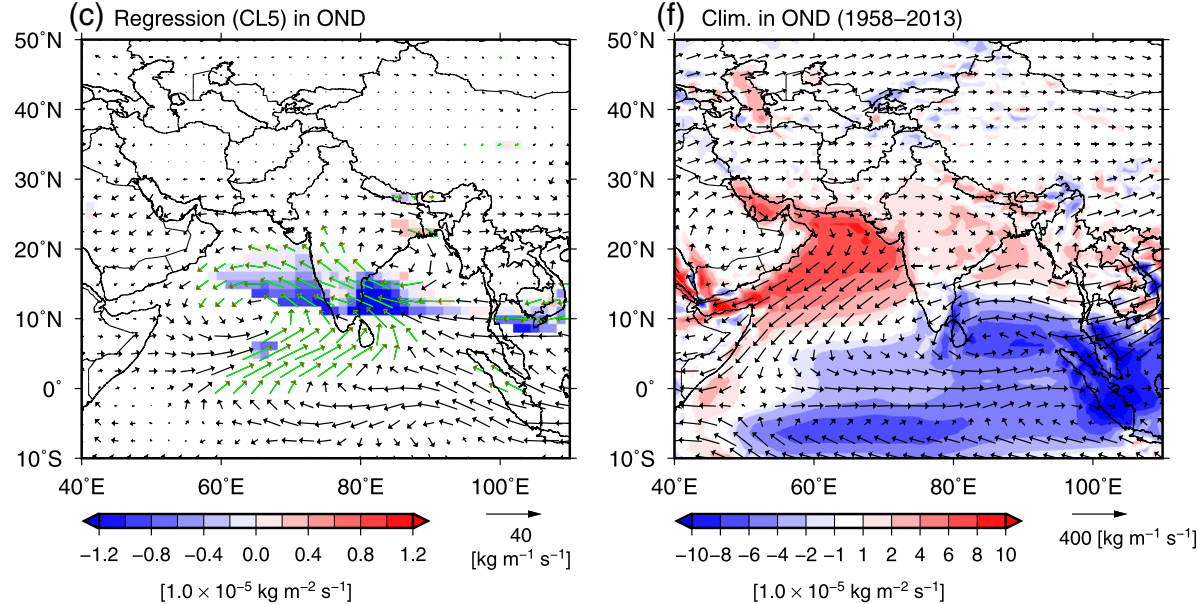

Fig. 10 Same as Fig. 8 but for the post-monsoon season (OND) The regression coefficient (objective variable is precipitation) between interannual variation of rainfall and water vapor flux $\left(\mathrm{kg} \mathrm{m}^{-1} \mathrm{~s}^{-1}\right)$ (vector) and its divergence $\left(\times 10^{-5} \mathrm{~kg} \mathrm{~m}^{-1} \mathrm{~s}^{-1}\right)$ (shaded) as the regression coefficient (objective variable is precipitation) for each cluster (a)-(e), and the distribution of climatological averaged values for 1958-2013 for the water vapor flux and divergence $(\mathbf{f})$

Ocean related to IAV affected the increase of JJAS precipitation in CL3 and CL6. The strength of the southeasterly wind around the Gangetic Plain, assumed related to activity of the monsoon trough, also induced water vapor flux convergence and it was found positively related to JJAS rainfall in CL3 and CL6. The positive anomaly of the 


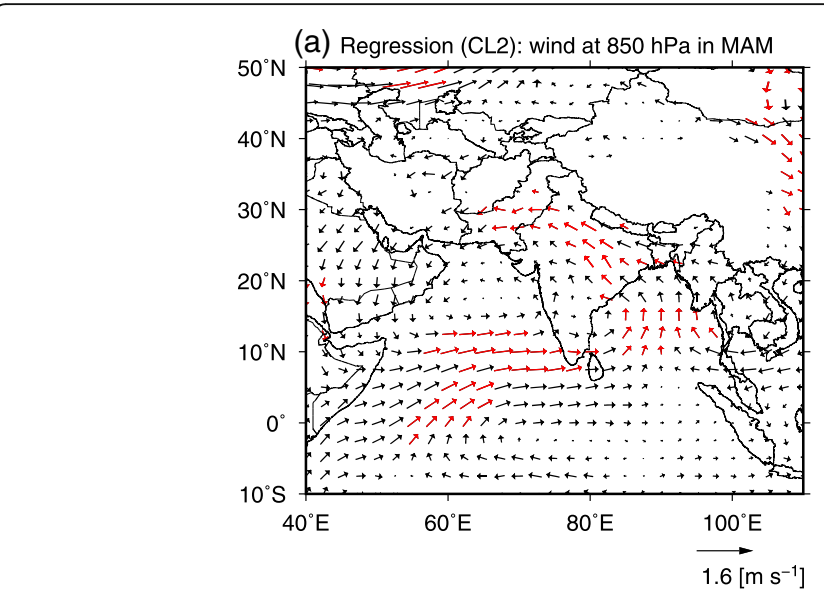

(d) Regression (CL6): wind at $850 \mathrm{hPa}$ in MAM

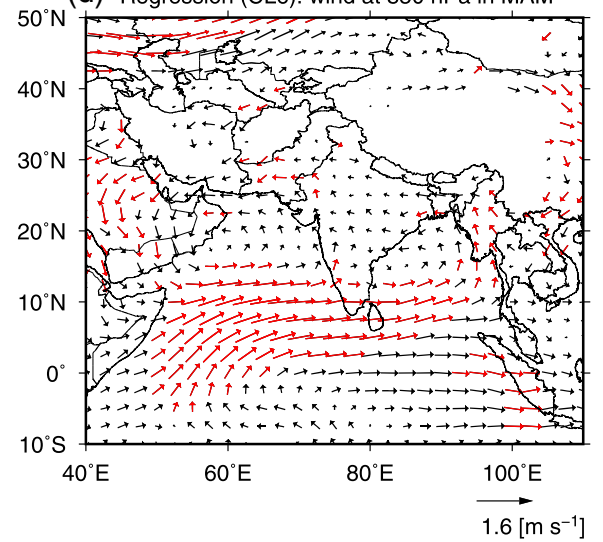

(e) Regression (CL7): wind at $850 \mathrm{hPa}$ in MAM
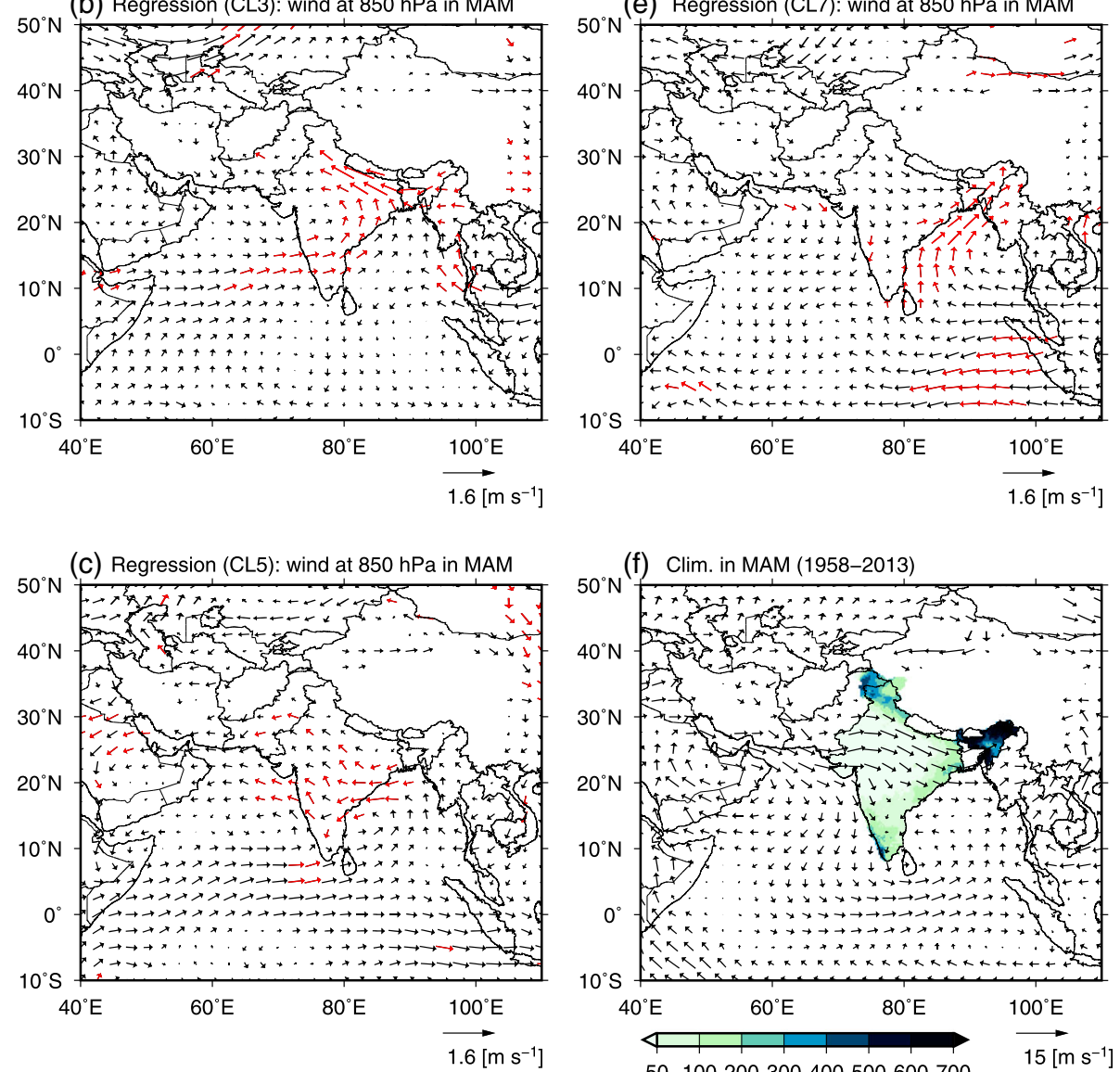

(f) Clim. in MAM (1958-2013)

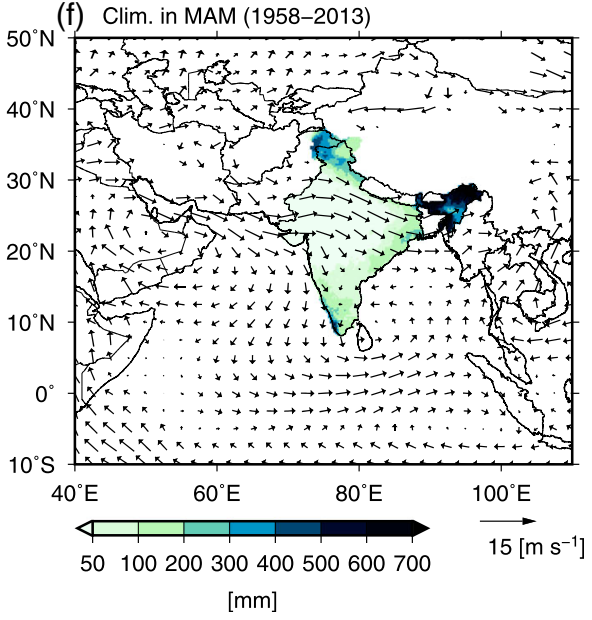

Fig. 11 Same as Fig. 7 but for the pre-monsoon season (MAM) The regression coefficient (objective variable is precipitation) between interannual variation of rainfall and the wind field at $850 \mathrm{hPa}\left(\mathrm{m} \mathrm{s}^{-1}\right)$ (vector) for each cluster $(\mathbf{a})-(\mathbf{e})$, and the distribution of the climatological values (averaged for 1958-2013) of seasonal precipitation and wind vectors at $850 \mathrm{hPa}$, as in Fig. 6a (f)

southwesterly water vapor flux over the equatorial Indian Ocean around $40^{\circ}-80^{\circ} \mathrm{E}$ was found related to the IAV of JJAS precipitation in all regions except CL7. For region CL7, the strength of the westerly anomaly around the foothills of the Himalayas was found related to the IAV of
JJAS precipitation. Thus, the IAV of precipitation in this region has no relationship with SWM flow (either the southwesterly flow over the Arabian Sea or the southeasterly flow over the Gangetic Plain). Moreover, the IAV of region CL5 was found not correlated with the SWM 

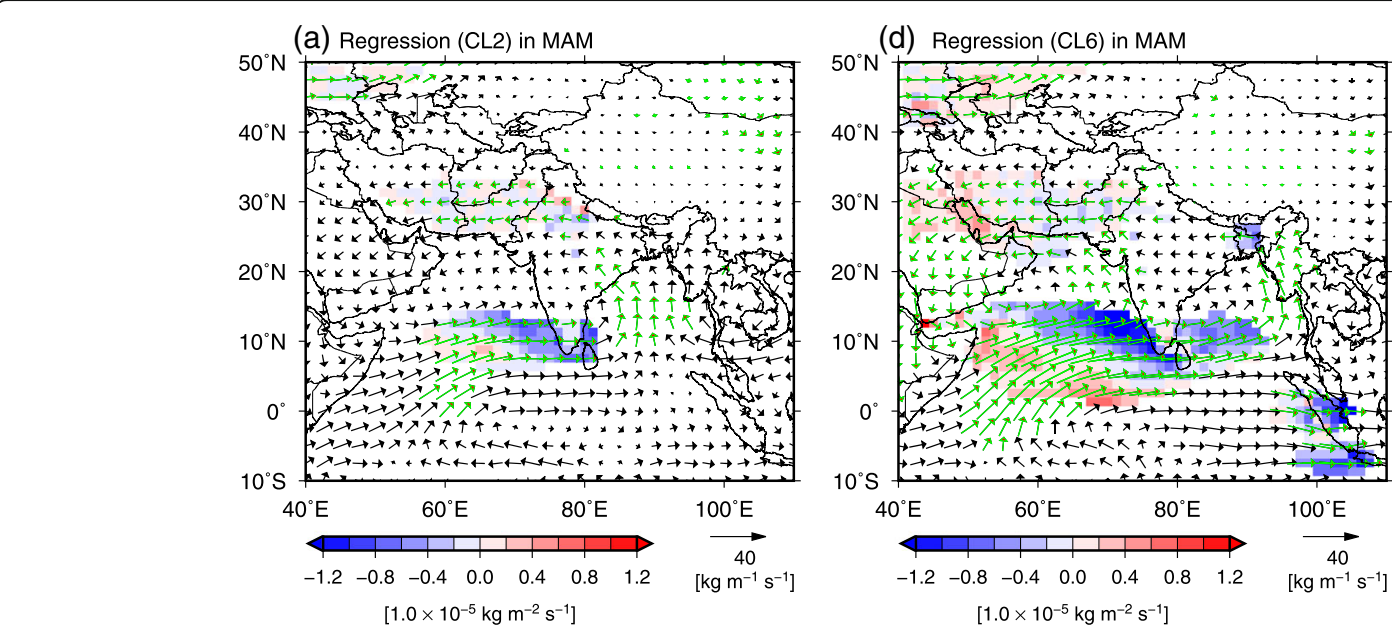

(b) Regression (CL3) in MAM

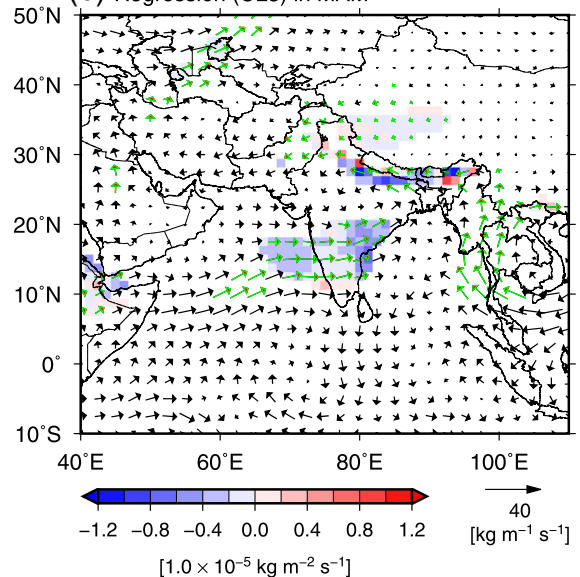

(e) Regression (CL7) in MAM

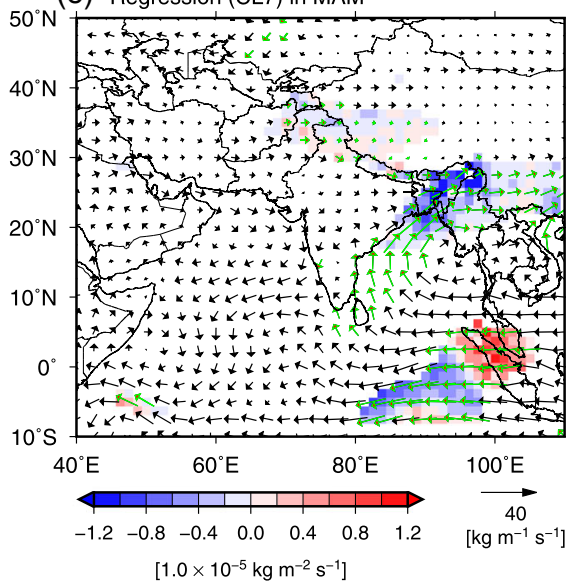

(c) Regression (CL5) in MAM
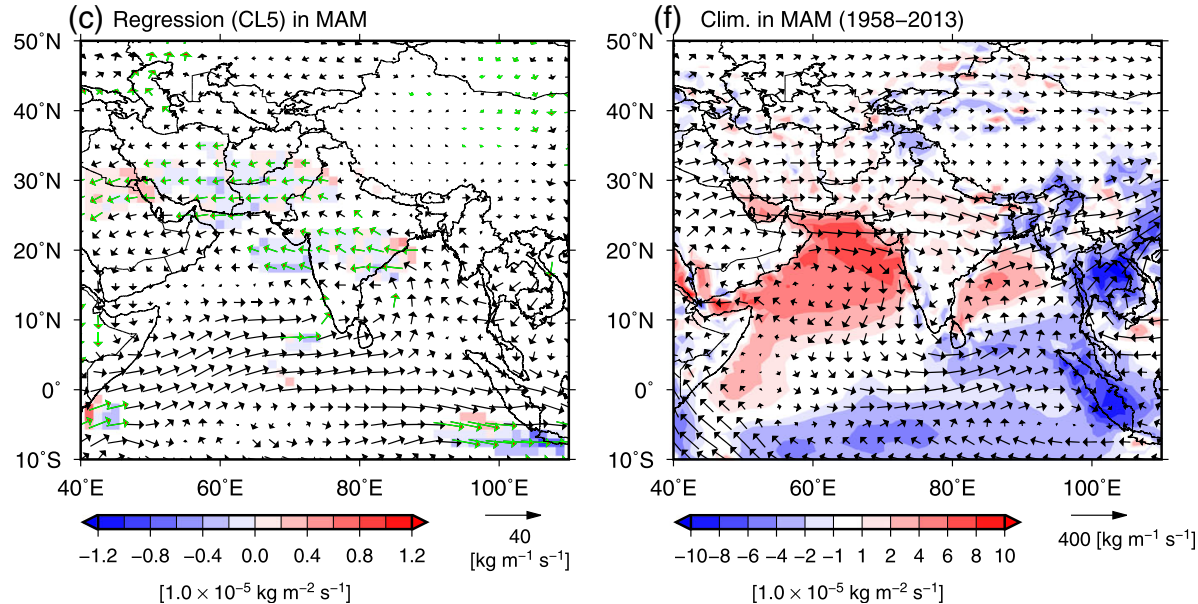

Fig. 12 Same as Fig. 8 but for the pre-monsoon season (MAM) The regression coefficient (objective variable is precipitation) between interannual variation of rainfall and water vapor flux $\left(\mathrm{kg} \mathrm{m}^{-1} \mathrm{~s}^{-1}\right)$ (vector) and its divergence $\left(\times 10^{-5} \mathrm{~kg} \mathrm{~m}^{-1} \mathrm{~s}^{-1}\right)$ (shaded) as the regression coefficient (objective variable is precipitation) for each cluster (a)-(e), and the distribution of climatological averaged values for 1958-2013 for the water vapor flux and divergence $(\mathbf{f})$

because of the weak relationship with the southwesterly or southeasterly flow over the Indian Ocean or the Gangetic Plain, respectively.
In the middle-term trend of the circulations, a suppressed anomaly of the SWM around the western part of the Arabian Sea was not related to the trend of precipitation in 
CL3 and CL6. The easterly shift of the SWM flow is favorable for increased rainfall in CL6. In contrast, the southwesterly flow distributed over a broad area of the Indian Ocean was found correlated with precipitation increase in CL3. Therefore, the responses to the SWM can be attributed to the regional differences between these two regions.

For the other season, a southeasterly anomaly that strengthens the NEM wind over the BoB was found related to the increase of precipitation in CL5 in the post-monsoon season. The southeasterly anomaly of water vapor flux and its convergence were positively related to CL5 rainfall over the middle to southeast coast of the subcontinent. Moreover, a signal of earlier onset of the SWM over the western Arabian Sea around $10^{\circ} \mathrm{N}$ was found related to pre-monsoon precipitation for all regions of India except CL7. The IAV of MAM precipitation in these regions was assumed strongly correlated with water vapor transport from a surrounding region over the northeastern states of India. In winter (JF), only the Himalayan area (including the northeastern states) receives rainfall and the IAV was found closely related to the westerly winds.

According to our results, relations between long-term circulation change and seasonal precipitation affected by the SWM or NEM were observed in limited regions. However, the responses of seasonal precipitation to atmospheric circulation were not simple. In particular, northeastern India showed IAVs or trends that were completely different to other regions. The effect of SWM or NEM variability on precipitation in this region can be considered very small. This relation should be investigated in detail in each region. Responses to some signals of atmospheric circulation, such as early onset of the SWM during the pre-monsoon season or a weak increase of water vapor flux around the Himalayan region in the pre-monsoon and post-monsoon seasons, should be examined closely in future research.

\section{Additional file}

Additional file 1: Correlation coefficients of summer (JJAS) precipitation between the cluster-averaged values and each grid for 1901-2013. Correlation coefficients of CL1 (a), CL2 (b), CL3 (c), CL4 (d), CL5 (e), CL6 (f), and $\mathrm{CL7}$ (g). Colored grids show the coefficients of correlation with statistical significance levels over 1\%. (EPS $1102 \mathrm{~kb}$ )

\footnotetext{
Abbreviations

AIR, AIR2: All-India Rainfall; BoB: Bay of Bengal; ENSO: El Niño-Southern Oscillation; IAV: Interannual variation; ITM: Indian Institute of Tropical Meteorology; IMD: Indian Meteorological Department; IMZ: Indian Monsoon Zone; JF: January and February; JJAS: June, July, August, and September; JRA55: Japanese 55-year reanalysis; LLJ: Low-level jet stream; MAM: March, April, and May; NEM: Northeast Monsoon; OND: October, November, and December; SD: Standard deviation; SWM: Southwest Monsoon
}

\section{Acknowledgements}

The authors appreciate the comments from the referees and editor that helped improve the manuscript. This work was supported by the Japan Society for the Promotion of Science (JSPS) Grants-in-Aid for Scientific Research (KAKENHI) Grant Numbers JP26220202 and JP18K12576, Joint Research Program of the Institute for Space-Earth Environmental Research, Nagoya University, and a grant for environmental research projects from the Sumitomo Foundation.

\section{Funding}

This work was supported by JSPS KAKENHI Grant Numbers JP26220202, JP18K12576, by the collaborative research program of the ISEE, Nagoya University, from 2016 to 2018, and by a grant for environmental research projects from the Sumitomo Foundation, 2017.

\section{Availability of data and materials}

Data sharing is not applicable to this article as no datasets were generated or analyzed during the current study.

\section{Authors' contributions}

AF proposed the topic and conceived and designed the study. JM purchased the rainfall data. AF analyzed the data. HK analyzed the data and helped with the interpretation. JM collaborated with the corresponding author in the construction of the manuscript. All authors read and approved the final manuscript.

\section{Authors' information}

AF is a lecturer in the Faculty of Humanities and Sciences at Kobe Gakuin University. HK is a researcher at the Institute for Space-Earth Environmental Research, Nagoya University. JM is the director of the Research Center for Climatology and a professor in the Department of Geography, Tokyo Metropolitan University.

\section{Competing interests}

The authors declare that they have no competing interests.

\section{Publisher's Note}

Springer Nature remains neutral with regard to jurisdictional claims in published maps and institutional affiliations.

\section{Author details}

${ }^{1}$ Faculty of Humanities and Sciences, Kobe Gakuin University, 518 Arise, Ikawadani-cho, Nishi-ku, Kobe, Hyogo 651-2180, Japan. ${ }^{2}$ Institute for Space-Earth Environmental Research, Nagoya University, Furo-cho, Chikusa-ku, Nagoya, Aichi 464-8601, Japan. ${ }^{3}$ Research Center for Climatology, Department of Geography, Tokyo Metropolitan University, 1-1 Minamiosawa, Hachioji, Tokyo 192-0397, Japan. ${ }^{4}$ Department of

Coupled-Ocean-Atmosphere-Land Processes Research, Japan Agency for Marine-Earth Science and Technology, 2-15 Natsushima-cho, Yokosuka, Kanagawa 237-0061, Japan.

Received: 5 April 2018 Accepted: 7 January 2019

Published online: 15 February 2019

\section{References}

Ananthakrishnan R, Soman MK (1988) The onset of the southwest monsoon over Kerala: 1901-1980. Int J Climatol 8:283-296 https://doi.org/10.1002/joc. 3370080305

Azad S, Vignesh TS, Narasimha R (2010) Periodicities in Indian monsoon rainfall over spectrally homogeneous regions. Int J Climatol 30:2289-2298 https:// doi.org/10.1002/joc.2045

Blanford HF (1886) Rainfall of India. Memoir of Indian Meteorological Department 2-4:668

Dash SK, Jenamani RK, Kalsi SR, Panda SK (2007) Some evidence of climate change in twentieth-century India. Clim Chang 85:299-321 https://doi.org/10. 1007/s10584-007-9305-9

Deka RL, Mahanta C, Pathak H, Nath KK, Das S (2013) Trends and fluctuations of rainfall regime in the Brahmaputra and Barak basins of Assam, India. Theor Appl Climatol 114:61-71 https://doi.org/10.1007/s00704-012-0820-x 
Fukushima A, Takahashi H (2012a) Regional and seasonal variability of rainfall characteristics in Nepal. Geograph Rev Japan 85:127-137 https://doi.org/10. 4157/grj.85.127

Fukushima A, Takahashi H (2012b) Relation between seasonal transition of circulations and premonsoon precipitation of the Himalayan foothills. Geographical Rep Tokyo Metropolitan Univ 47:27-37 http://hdl.handle.net/ $10748 / 5040$

Gadgil S (2003) The Indian monsoon and its variability. Annu Rev Earth Planet Sci 31:429-467 https://doi.org/10.1146/annurev.earth.31.100901.141251

Gadgil S, lyengar RN (1980) Cluster analysis of rainfall station of the Indian peninsula. Quart J R Met Soc 106:873-886 https://doi.org/10.1002/qj. 49710645016

Gadgil S, Yadumani, Joshi NV (1993) Coherent rainfall zones of the Indian region. Int J Climatol 13:547-566 https://doi.org/10.1002/joc.3370130506

George G, Charlotte BV, Runchith RD (2011) Interannual variation of northeast monsoon rainfall over southern peninsular India. Ind J Geo-Marine Sci 40:98104 http://nopr.niscair.res.in/handle/123456789/11376

Goswami BN, VenugopalV SD, MadhusoodananMS XPK (2006) Increasing trend of extreme rain events over India in a warming environment. Science 314:14421445 https://doi.org/10.1126/science.1132027

lyengar R. N., Basak P., (1994) Regionalization of Indian monsoon rainfall and long-term variability signals. International Journal of Climatology 14 (10): 1095-1114.

Jain SK, Kumar V, Saharia M (2013) Analysis of rainfall and temperature trends in Northeast India. Int J Climatol 33:968-978 https://doi.org/10.1002/joc.3483

Joseph PV, Simon A (2005) Weakening trend of the southwest monsoon current through peninsular India from 1950 to the present. Curr Sci 89:687-694 https://www.jstor.org/stable/24111169

Kakade SB, Kulkarni A (2017) Seasonal prediction of summer monsoon rainfall over cluster regions of India. J Earth Syst Sci 126:34 https://doi.org/10.1007/ s12040-017-0811-5

Karmakar N, Chakraborty A, Nanjundiah RS (2015) Decreasing internsity of monsoon low-frequency intraseasonal variability over India. Environ Res Lett 10:054018 https://doi.org/10.1088/1748-9326/10/5/054018

Karmakar N, Chakraborty A, Nanjundiah RS (2017) Increased sporadic extremes decrease the intraseasonal variability in the Indian summe monsoon rainfall. Sci Rep 7:7824 https://doi.org/10.1038/s41598-017-07529-6

Kendall MG (1938) A new measure of rank correlation. Biometrika 30:81-93 https://doi.org/10.1093/biomet/30.1-2.81

Kobayashi S, Ota Y, Harada Y, Ebita A, Moriya M, Onoda H, Onogi K, Kamahori H, Kobayashi C, Endo H, Miyaoka K, Takahashi K (2015) The JRA-55 reanalysis: general specifications and basic characteristics. J Meteor Soc Japan 93:5-48 https://doi.org/10.2151/jmsj.2015-001

Krishnamurti V, Shukla J (2000) Intraseasonal and interannual variability of rainfall over India. J Clim 13:4366-4377 https://doi.org/10.1175/15200442(2000)013<0001:IAIVOR>2.0.CO;2

Kulkarni A (2017) Homogeneous clusters over India using probability density function of daily rainfall. Theor Appl Climatol 129:633 https://doi.org/10.1007/ s00704-016-1808-8

Kulkarni A, R. H. Kripalani, S. V. Singh, (1992) Classification of summer monsoon rainfall patterns over India. International Journal of Climatology 12 (3):269-280.

Kumar V, Jain SK, Singh Y (2010) Analysis of long-term rainfall trends in India. Hydro Sci J 55:484-496 https://doi.org/10.1080/02626667.2010.481373.

Lang JT, Barros AP (2004) Winter storms in the central Himalayas. J Meteor Soc Japan 82:829-844 https://doi.org/10.2151/jmsj.2004.829

Lau KMW, Waliser ED (2005) Intraseasonal variability in the Atmosphere-Ocean climate system. Springer-Verlag, Berlin Heidelberg https://doi.org/10.1007/ 978-3-642-13914-7

Mann HB (1945) Nonparametric tests against trend. Econometrica 13:245-259 https://www.jstor.org/stable/pdf/1907187.pdf

Naidu CV, Durgalakshmi K, Krishna KM, Rao SR, Satyanarayana GC, Lakshminarayana P, Rao LM (2009) Is summer monsoon rainfall decreasing over India in the global warming era? J Geophy Res 114:D24108 https://doi. org/10.1029/2008JD011288

Pai DS, Sridhar L, Rajeevan M, Sreejith OP, Satbhai NS, Mukhopadyay B (2014) Development of a new high spatial resolution $\left(0.25^{\circ} \times 0.25^{\circ}\right)$ long period (1901-2010) daily gridded rainfall data set over India and its comparison with existing data sets over the region. MAUSAM 65:1-18

Pant GB, Kumar Rupa K (1997) Climate of South Asia. Wiley, Chichester, p 320 ISBN 0-471-94948-5
Parthasarathy B, Kumar RK, Munot AA (1993) Homogeneous Indian monsoon rainfall: Variability and prediction. Proc Indian Acad Sci 102:121-155 https:// www.ias.ac.in/article/fulltext/jess/102/01/0121-0155

Parthasarathy B, Munot AA, Kothawale DR (1994) All-India monthly and seasonal rainfall series: 1871-1993. Theor Appl Clim 49:217-224 https://doi.org/10. 1007/BF00867461

Parthasarathy B, Munot AA, Kothawale DR (1995) Monthly and seasonal rainfall series for All-India homogeneous regions and meteorological subdivisions: 1871-1994. Contributions from Indian Institute of Tropical Meteorolgy, Research Report RR-065

Prakash S, Mahesh C, Sathiyamoorthy V, Gairola RM (2013) Increasing trend of northeast monsoon rainfall over the equatorial Indian Ocean and peninsular India. Theor Appl Climatol 112:185-191 https://doi.org/10.1007/s00704-012-0719-6

Rajeevan M, Bhate J, Kale JD, Lal B (2006) A high resolution daily gridded rainfall for the Indian region: analysis of break and active monsoon spells. Curr Sci 91:296-306 https://www.jstor.org/stable/24094135

Rajeevan M, Gadgil S, Bhate J (2010) Active and break spells of the Indian summer monsoon. J Earth Syst Sci 119:229-247 https://doi.org/10.1007/ s12040-010-0019-4

Roxy MK, Ritika K, Terray P, Murtugudde R, Ashok K, Goswami BN (2015) Drying of Indian subcontinent by rapid Indian Ocean warming and a weakening land-sea thermal gradient. Nat Commun 6:7423 https://doi.org/10.1038/ ncomms8423

Saikranthi K, Narayana Rao T, Rajeevan M, Vijaya Bhaskara Rao S (2013) Identification and validation of homogeneous rainfall zones in India using correlation analysis. J Hydrometeorol 14:304-317 https://doi.org/10.1175/ JHM-D-12-071.1

Satyanara P, Srinivas W (2011) Regionalization of precipitation in data sparse areas using large scale atmospheric variables - a fuzzy clustering approach. J Hydrol 405:462-473 https://doi.org/10.1016/j.jhydrol.2011.05.044

Sikka DR, Gadgil S (1980) On the maximum cloud zone and the ITCZ over Indian longitudes during the southwest monsoon. Mon Wea Rev 108:1840-1853 https://doi.org/10.1175/1520-0493(1980)108<1840:OTMCZA>2.0.CO;2

Singh N, Sontakke NA (1999) On the variability and prediction of rainfall in the post-monsoon season over India. Int J Climatol 19:309-339 https://doi.org/ 10.1002/(SICI)1097-0088(19990315)19:3<309::AID-JOC361>3.0.CO;2-\%23

Wahiduzzaman M, Oliver ECJ, Wotherspoon SJ, Holbrook NJ (2017) A climatological model of North Indian Ocean tropical cyclone genesis, tracks and landfall. Clim Dyn 49:2585-2604 https://doi.org/10.1007/ s00382-016-3461-4

Yadav RK, Rupa Kumar K, Rajeevan M (2007) Role of Indian Ocean Sea surface temperature in modulating northwest Indian winter precipitation variability. Theor Appl Climatol 87:73-83 https://doi.org/10.1007/s00704-005-0221-5

Zubair L, Ropelewski CF (2006) The strengthening relationship between ENSO and northern monsoon rainfall over Sri Lanka and southern India. J Clim 19: 1567-1575 https://doi.org/10.1175/JCLI3670.1

\section{Submit your manuscript to a SpringerOpen ${ }^{\circ}$ journal and benefit from:}

- Convenient online submission

- Rigorous peer review

- Open access: articles freely available online

- High visibility within the field

- Retaining the copyright to your article

Submit your next manuscript at $\boldsymbol{\nabla}$ springeropen.com 